\title{
VERIFICATION POSTDIAGNOSTIC DECISIONS TESTED OF ARTILLERY FUSES
}

\section{WERYFIKACJA DECYZJI PODIAGNOSTYCZNYCH BADANYCH ZAPALNIKÓW ARTYLERYJSKICH}

\author{
Dariusz Ampula \\ Military Institute of Armament Technology \\ Wojskowy Instytut Techniczny Uzbrojenia
}

\begin{abstract}
A statistical analysis of multiyear laboratory test results and dynamic tests chosen type of artillery fuses is presented in this article as the aim to testify influence of natural ageing process on quality indicators during long - time exploitation. The influence of exploitation time on taking shooting test decisions relating the quality of lots after conducted laboratory tests and on different inconsistencies classes which stepped out during these tests were analysed. The analysis of exploitation time influence on diagnostic decisions taking after conducted shooting tests and on occurrence inconsistences in the establish classes were also presented. The conducted statistical analysis suggested assumption, that there is possibility of changing of estimate module in the test's methodology applied until now. The modification of this estimate module will not influence negatively on the quality of further diagnostic tests conducted, and it will not influence negatively on correct evaluation of prediction process tested elements of ammunition which the artillery fuses are. Performed the statistical analysis can be essentially relevant to modify tests methodology of the artillery fuses.
\end{abstract}

Keywords: exploitation, inconsistences, testing cycle, decision, test, properties.

Streszczenie: $W$ artykule przedstawiono analize statystyczna wieloletnich wyników badań laboratoryjnych oraz badań dynamicznych wybranych typów zapalników artyleryjskich $w$ celu zbadania wptywu procesu naturalnego starzenia na wskaźniki jakościowe podczas dtugoletniej eksploatacji. Analizowano wpływ czasu eksploatacji na podjęte decyzje badać strzelaniem dotyczace jakości partii po przeprowadzonych badaniach laboratoryjnych oraz na różne klasy niezgodności jakie wystapity podczas tych badań. Przedstawiono także analizy wptywu czasu eksploatacji na decyzje diagnostyczne podjęte po przeprowadzonych badaniach dynamicznych strzelaniem a także na występowanie niezgodności $w$ ustalonych klasach. Przeprowadzona analiza statystyczna nasuwa przypuszczenie, że możliwa jest zmiana modulu ocenowego $w$ dotychczasowej metodyce badawczej. Modyfikacja tego modulu ocenowego nie wptynie negatywnie na jakość prowadzonych dalszych badań diagnostycznych, ani też nie wptynie negatywnie na prawidlowa ocene procesu predykcji badanych elementów środków bojowych jakimi sa zapalniki artyleryjskie. Przeprowadzona analiza statystyczna może mieć istotne znaczenie dla modyfikacji metodyki badań zapalników artyleryjskich.

Stowa kluczowe: eksploatacja, niezgodności, cykl badania, decyzja, badanie, wtaściwości. 
Verification postdiagnostic decisions tested of artillery fuses

Weryfikacja decyzji podiagnostycznych badanych zapalników artyleryjskich

\section{Introduction}

The artillery fuses [2] are precise elements of ammunition intended to initiate the working of projectile in the target or on the track of flight in time constructively established or programmed before the shot. Like other elements of ammunition they are subject of systematic diagnostic tests. The first stage of tests are laboratory tests conducted of course in compliance with binding methodology test [1]. The range of these tests and their frequency are determined by higher indicated methodology tests. As a result of these tests, the test lot of artillery fuses can be found good and the period of safe exploitation is determined by following three or five years (decisions B3 or B5). It can also be negative decision undertaken which finds that as the result of ascertained inconsistencies during tests the lot should be withdrawn from usage due to safety of exploitation (decision W). But decision about not end of current cycle of test can be undertaken and this lot should be to tested by dynamical shooting (decision BS). This test relies on execution of dynamic tests whose range, conditions and possible to undertake diagnostic decisions after these tests, determines the current methodology test.

In this article the author takes an attempt to execute of statistical analysis of chosen type of tested artillery fuses. So, a purpose of the article is verification and to rate the statistical evaluation undertaken decisions of shooting test after conducted laboratory tests and penetrating analysis of these test results, showing different kinds of inconsistencies which were diagnosed during these laboratory tests. Analysis of diagnostic decisions undertaken after conducted shooting dynamic tests together with analysis of different kinds of inconsistencies which appeared during these tests also was executed.

The statistical analysis subjected of M-5, MD-8, MG-37, MG-57 and T-5 fuse types. They were applied in $120 \mathrm{~mm}$ mortar cartridges, $85 \mathrm{~mm}$ armour - piercing tracer cartridges, $37 \mathrm{~mm}$ fragment - tracer cartridges, $57 \mathrm{~mm}$ fragment - tracer cartridges and $85 \mathrm{~mm}$ anti - aircraft fragment cartridges. The sets of these fuse types were not analysed earlier. The executed analysis includes all previous laboratory test results and dynamic shooting fuse tests which were executed to the end of 2010. The later tests were not considered because of change of methodology test. The estimate module of results test in the new methodology test did not undergo change, that's why the author of the article made also an attempt of modification this module.

\section{Fuses features}

The main exploitive features according to [1] that fuses should be characterised are: the safety, reliability of working and durability i. e. the conditions appearing during this exploitation resistance. In detail it is: the safety guaranteed during the production of details and groups, assembly, control and approval tests and transportation. In the process of exploitation such features are the safety: during shooting, long - time storage, maintenance, regulations, repair, loadings, unloadings and movements by different land, water and air transport equipment. 
The tested fuse features according to [1] are divided into five importance classes: $\mathrm{A}, \mathrm{B}, \mathrm{C}, \mathrm{D}$ and $\mathrm{E}$. The classes $\mathrm{C}, \mathrm{D}$ and $\mathrm{E}$ characterise safety and reliable operations, however $\mathrm{A}$ and $\mathrm{B}$ classes characterise the degree of advancing natural aging process.

This analysis will not be include inconsistencies D and E classes, because in the moment of their appearance, the tested fuse lot receives in compliance with binding methodology test other diagnostic decision than decision the shooting test. Inconsistencies of this type did not appear during made checks analysed fuse lots. So we will be considering only inconsistencies A, B and C classes.

The undertaking of decision of shooting test after laboratory tests, for tested fuse lots, is conditioned an appearance define amount of inconsistencies A, B or C classes. The quantity of these inconsistencies is recorded separately in evaluation tables in methodology test for every kind of fuse. The elaboration of these evaluation tables, was preceded by lots of statistical analyses executed for tested fuse types.

\section{The analysis of tested fuses}

To statistical analysis subjected results of laboratory tests samples coming from stored fuse lots of following types: M-5, MD-8, MG-37, MG-57 and T-5.

The higher mentioned sample sets, received during laboratory tests decision of shooting test. The diagnostic fuse tests conducted in compliance with the methodology tests [1]. The purpose of this analysis is to recognise the processes of natural aging of analysed fuses, the determine the impact of these processes on their quality indicators and designation safe periods of prediction for analysed fuse types.

In the statistical practice testifying influence of one factor on other limits to test dependence between these factors. In this article there are only most essential dependences which show mutual relation of analysed sizes.

The methods analysis of regression and linear correlation permitting evaluation and definition character of dependence were applied to the statistical analysis. Also crossed out for every graphs $95 \%$ confidence interval of analysed sizes. The specialist statistical software [3], whose Institute owns was used. Only the most essential and in the subjective opinion of the author of article most significant graphs created were analysed and discussed in article.

\section{Exploitation time and laboratory diagnostic decisions}

The most general quality of coefficient exploited fuse lots is the decision of concerning of this lot, undertaken after testing coming from its sample. Undertaken decisions of shooting test during the first laboratory test will be considered as already remembered earlier only for purposes of the present analysis. These decisions tell us that tested fuse lot is unfit to further exploitation until the cycle test is finished. To finish this cycle test, we should conduct dynamic shooting test. After these tests, given cycle test should be finished and final decision should be made. 
Verification postdiagnostic decisions tested of artillery fuses

Weryfikacja decyzji podiagnostycznych badanych zapalników artyleryjskich

This decision can be positive, this lot can be intended to usage in the first order or it can be negative, so it can be withdrawn from exploitation.

In this analysis results of again shooting tests are not considered, because this cycle test decision lengthens. Therefore, the results of these tests are not comparable directly with results of shooting tests and do not create homogeneous sets in the opinion author of article.

Quality of the whole set of kind lots of fuses in the moment of test can depends from exploitation period individual lots of this set and from decision about quality these lots undertaken as result of diagnostic tests was accepted. An effect of influence of this time of exploitation is occurrence fuse aging changes able to cause the formation of inconsistencies due to individual properties.

At the testing of its dependence character dependent variable is fraction (percentage) undertaken decisions of shooting tests. This fraction is therefore, a relation number of undertaken decision of shooting tests to general quantity lots tested in given exploitation age analysed. As an independent variable taken exploitation time to the moment of given test. This time is counted in years as the difference between year of given test and production year tested fuse lots.

The graphs $1 \div 5$ present fraction decisions of shooting test in the function of exploitation time. On the basis broken curves representing individual fuse types can declare that together with change of exploitation time, the tendency of changing fraction decisions of shooting time appears.

The courses of these curves for two fuse type (MD-8 and T-5) indicate the existence of growing tendency i. e. the fraction decisions growth of shooting test in dependence on exploitation time. Coefficients of linear correlation are $r=0,2107$ for MD-8 fuses (fig. 2) and $r=0,3214$ for T-5 fuses (fig. 5). These measures are positive, so passage of exploitation time causes increase fraction undertaken decisions of shooting time.

The courses of the next two fuse types (MG-37 and MG-57) show on existence decreasing tendency i. e. follows the fraction decisions fall of shooting tests in dependence on exploitation time. Coefficients of linear correlation are $r=-0,372$ for MG-37 fuses (fig. 3) and $r=-0,4804$ for MG-57 fuses (fig. 4). These measures are negative that is passage of exploitation time causes reduce fraction undertaken decisions of shooting tests.

In one case we have to deal with the constant coefficient value of linear correlation approximately $\mathrm{r}=0,0063$, which informs us about proportion as passage of exploitation time, fraction decisions of shooting tests is almost on the constant level (this are M-5 fuses fig. 1). 


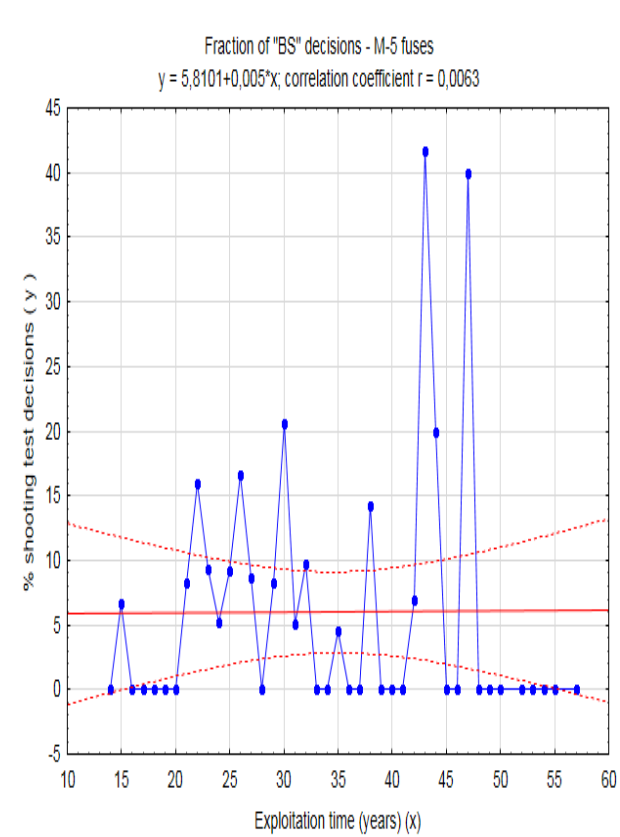

Fig.1 Graph of dependence between the exploitation time and fraction decision shooting test and regression line describing this dependence for M-5 fuses.

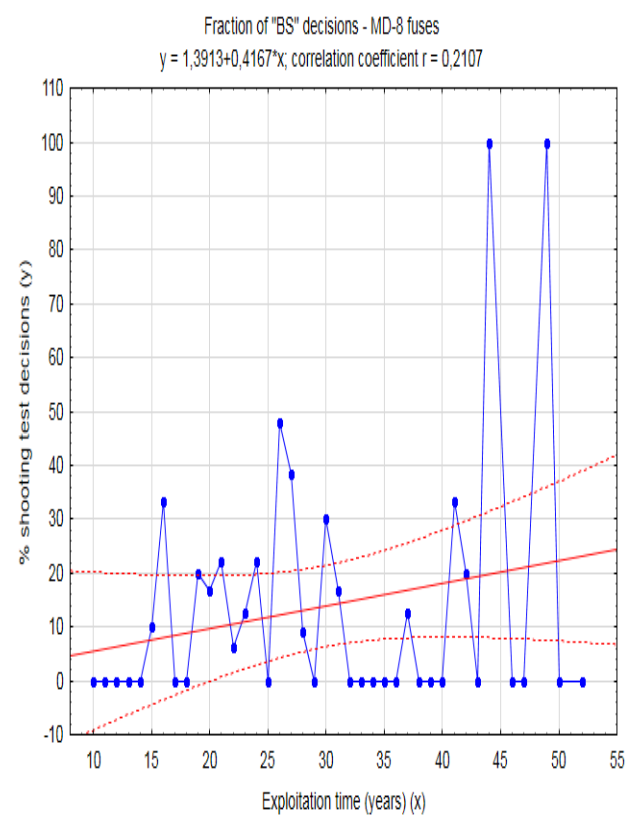

Fig.2 Graph of dependence between the exploitation time and fraction decision shooting test and regression line describing this dependence for MD-8 fuses.

\section{Inconsistencies in laboratory tests in the dependence exploitation time}

The next element of analysis is presentation of dependence dispersion of inconsistencies belonging to individual classes of inconsistencies from exploitation time tested fuse lots.

As independent variable taken exploitation time to moment of the tests, however as dependent variable taken quantities of inconsistencies in the individual tested classes. On the graphs $6 \div 15$ there are dispersion inconsistencies of individual classes for analysed fuses is presented in this article. Not all classes of inconsistencies were presented on enclosed diagrams due to little quantities of inconsistencies which appeared during laboratory tests.

On the graphs 6 and 7 there are diagrams of dependence between inconsistencies A and $B$ classes presented in the function of exploitation time for M-5 fuse types. In both cases there is a decreasing tendency, that goes together with the exploitation time growth follows reduce analysed classes of inconsistencies. Coefficient values of linear correlation are $\mathrm{r}=-0,2182$ (fig. 6) in case of inconsistencies of A class and $r=-0,2331$ (fig. 7) in case of inconsistencies of B class. Inconsistencies of C class were not considered due to the too little quantity affirmed inconsistencies of this class during laboratory tests. 
Verification postdiagnostic decisions tested of artillery fuses Weryfikacja decyzji podiagnostycznych badanych zapalników artyleryjskich

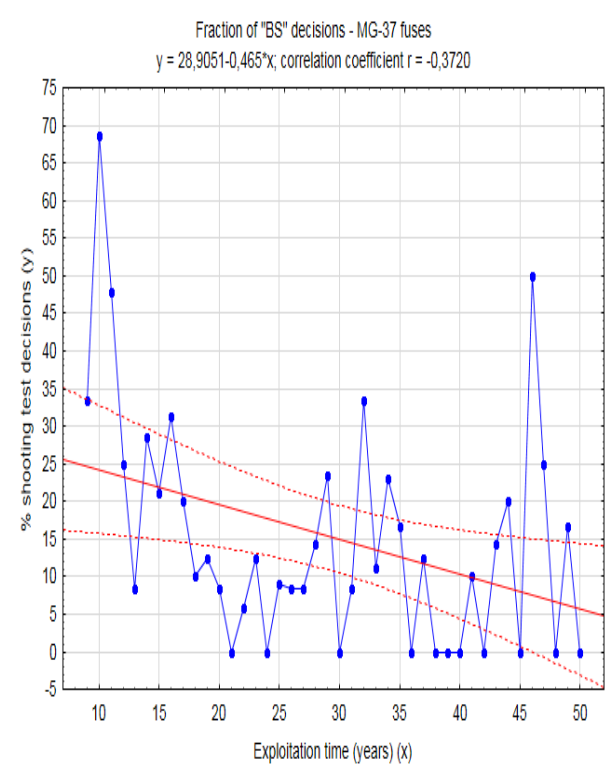

Fig.3 Graph of dependence between the exploitation time and fraction decision shooting test and regression line describing this dependence for MG-37 fuses.

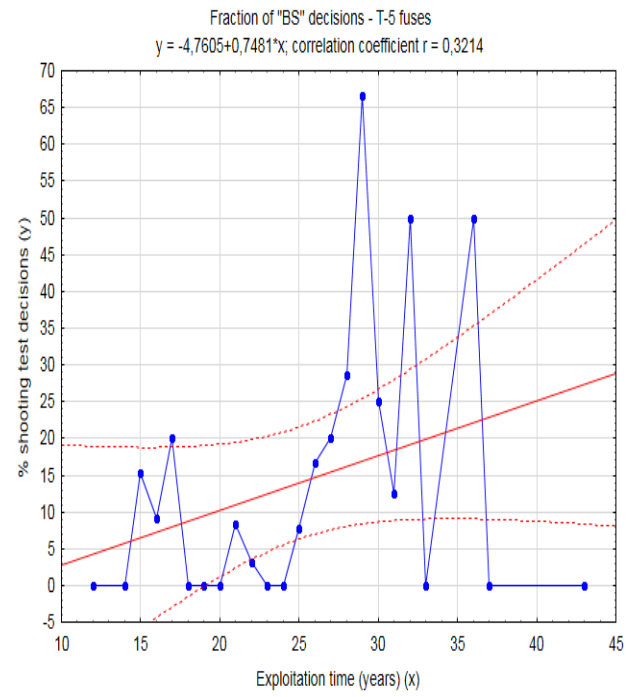

Fig.5 Graph of dependence between the exploitation time and fraction decision shooting test and regression line describing this dependence for T-5 fuses.

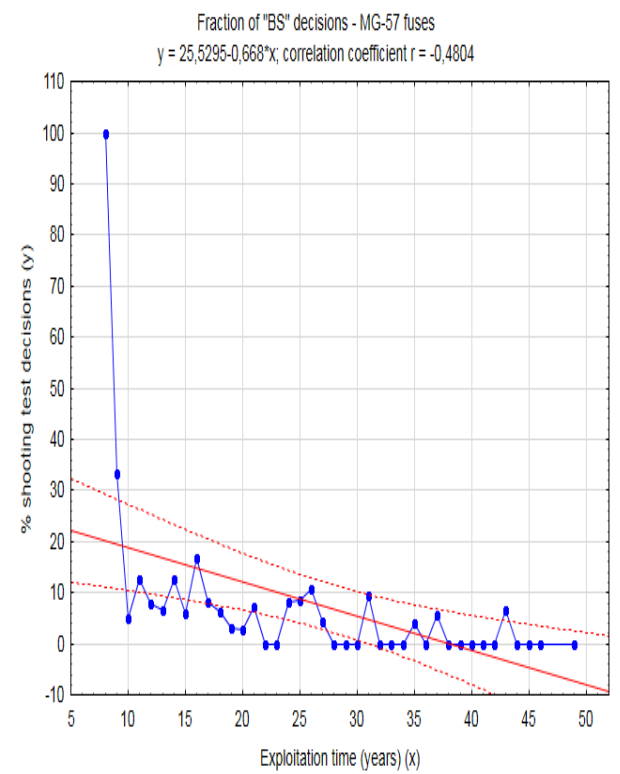

Fig.4 Graph of dependence between the exploitation time and fraction decision shooting test and regression line describing this dependence for MG-57 fuses.

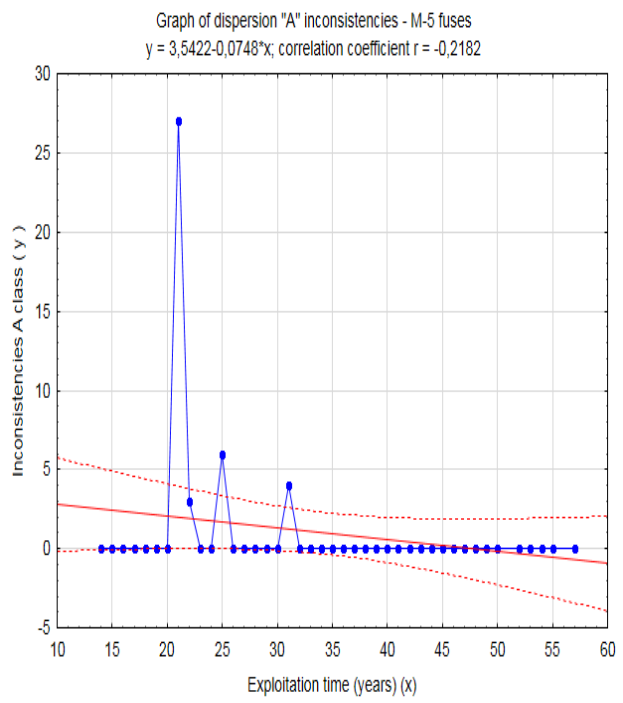

Fig.6 Inconsistencies of A class in the dependence from exploitation time and regression line describing this dependence for M-5 fuses. 


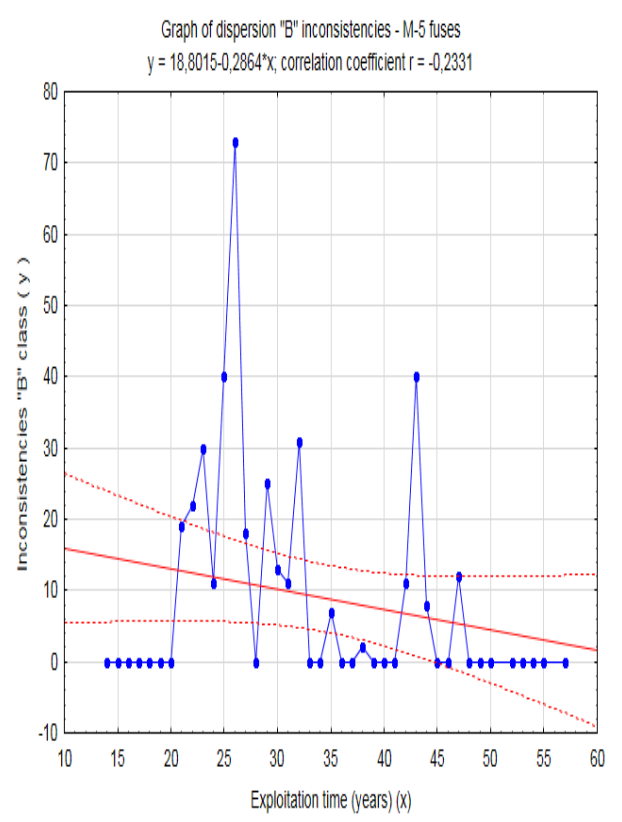

Fig.7 Inconsistencies of B class in the dependence from exploitation time and regression line describing this dependence for M-5 fuses.

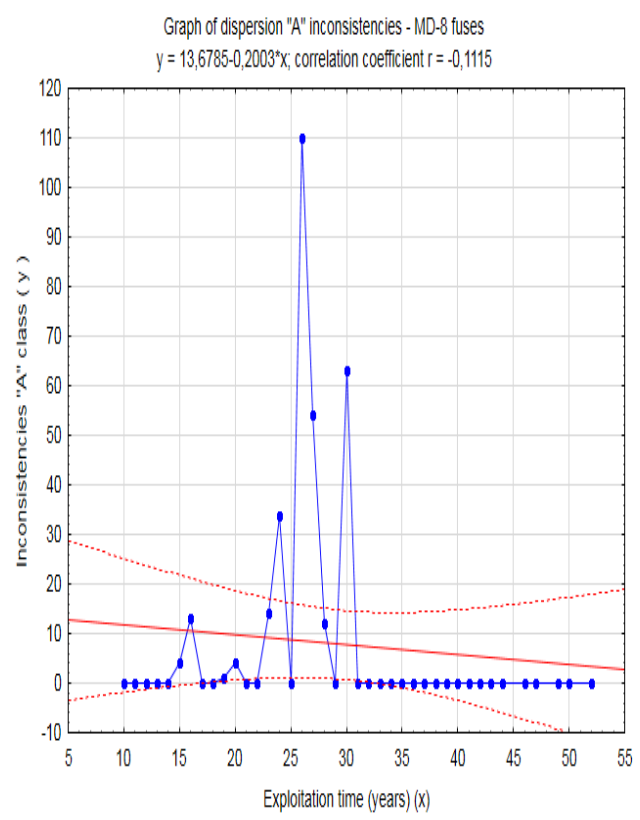

Fig. 8 Inconsistencies of A class in the dependence from exploitation time and regression line describing this dependence for $M D-8$ fuses.

In the case of MD-8 fuse types, curves presented on graphs 8, 9 and 10 indicate different change tendencies of analysed inconsistencies classes from exploitation time. Inconsistencies A and C classes (fig. 8 and 10) show decreasing tendency. Coefficient values of linear correlation are $r=-0,1115$ for inconsistencies of A class and $r=-0,128$ for inconsistencies of $C$ class. However, inconsistencies of $\mathrm{B}$ class show slightly increasing tendency. The coefficient value of linear correlation is $r=0,0191$ (fig. 9), that is inconsistencies of B class are almost on constant level during considered period of time.

On the graph 11 there is course of curve inconsistencies of $\mathrm{C}$ class in dependence from exploitation time for MG-37 fuses. The negative coefficient value of linear correlation is approximately $\mathrm{r}=-0,488$ and testifies about pronounced decreasing tendency this class of inconsistencies in dependence from exploitation time. Inconsistencies of A and B classes, due to their little quantity of occurrence were not analysed.

In the case of MG-57 fuse types, similar situation can be observed. Only inconsistencies of $\mathrm{C}$ class could be considered. From the graph it is visible (fig. 12), that curve has decreasing tendency. The coefficient value of linear correlation is $\mathrm{r}=-0,6228$ what testifies about pronounced decreasing inconsistencies of $\mathrm{C}$ class in proportion as passage exploitation time. 
Verification postdiagnostic decisions tested of artillery fuses

Weryfikacja decyzji podiagnostycznych badanych zapalników artyleryjskich

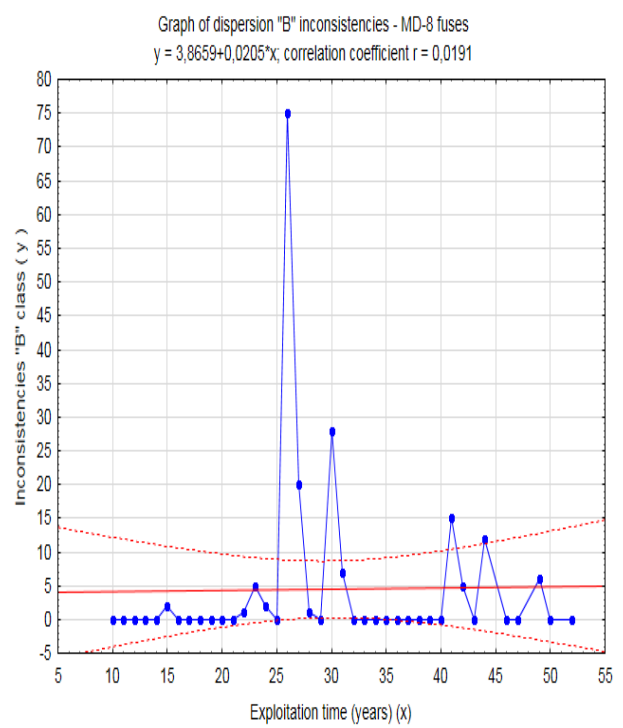

Fig. 9 Inconsistencies of $B$ class in the dependence from exploitation time and regression line describing this dependence for MD-8 fuses.

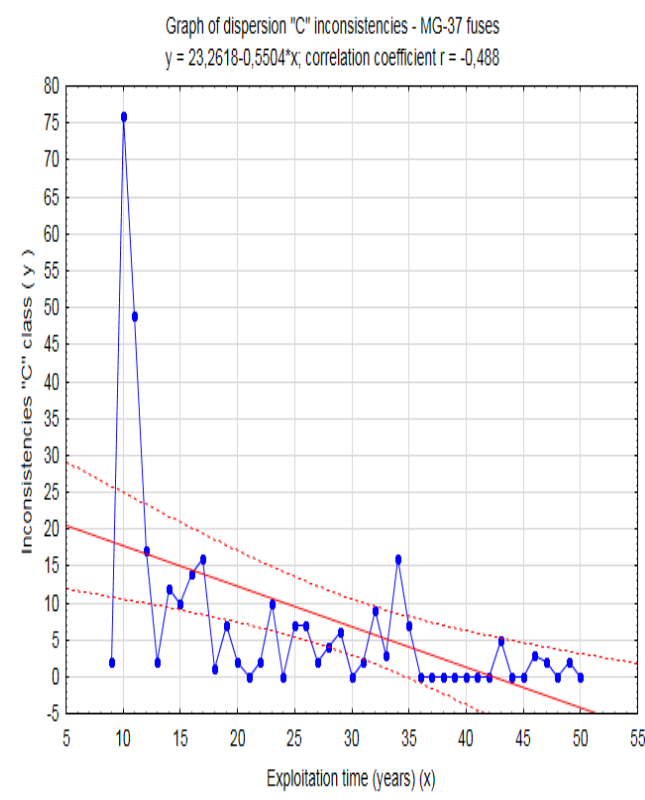

Fig. 11 Inconsistencies of $C$ class in the dependence from exploitation time and regression line describing this dependence for $M G-37$ fuses.

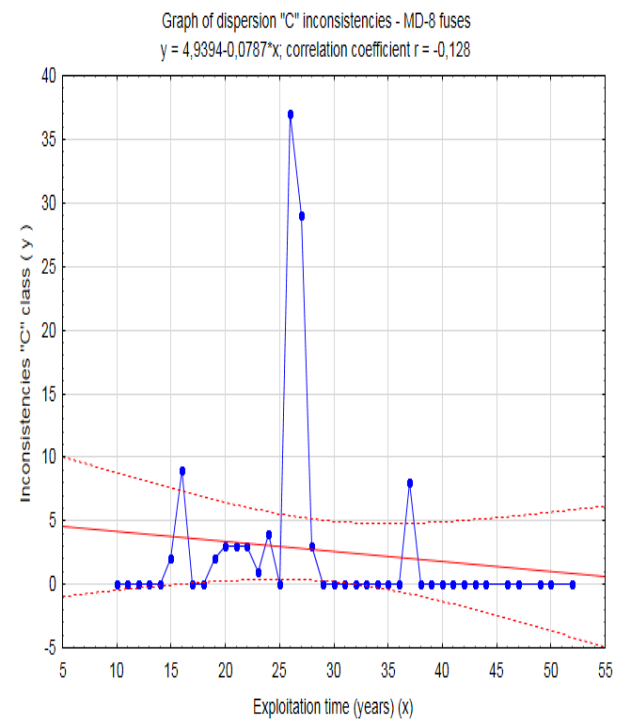

Fig. 10 Inconsistencies of $C$ class in the dependence from exploitation time and regression line describing this dependence for $M D-8$ fuses.

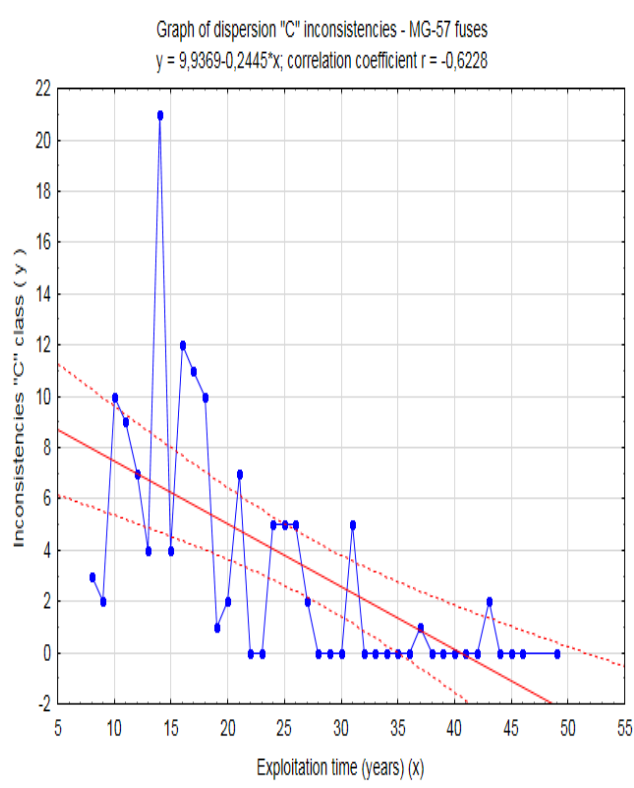

Fig. 12 Inconsistencies of C class in the dependence from exploitation time and regression line describing this dependence for MG-57 fuses. 
On the figures $13 \div 15$ graphs dependence inconsistencies of $\mathrm{A}, \mathrm{B}$ and $\mathrm{C}$ classes in relations to exploitation time for T-5 fuses are presented. In case inconsistencies of $\mathrm{A}$ and $\mathrm{B}$ classes decreasing tendency can be observed, that is together with passage exploitation time follows reductions of inconsistencies these classes. Coefficients values of linear correlation are for inconsistencies of $A$ class $r=-0,3583$ (fig. 13) and $r=-0,0406$ for inconsistencies of B class. However, in case of inconsistencies of $\mathrm{C}$ class we see increasing tendency. The coefficient value of linear correlation is $\mathrm{r}=0,1052$ (fig. 15).

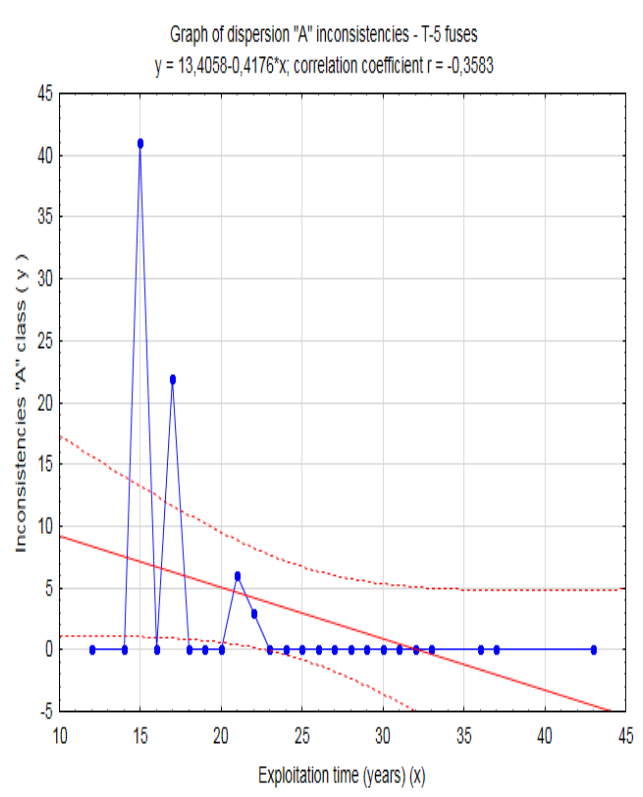

Fig. 13 Inconsistencies of A class in the dependence from exploitation time and regression line describing this dependence for T-5 fuses.

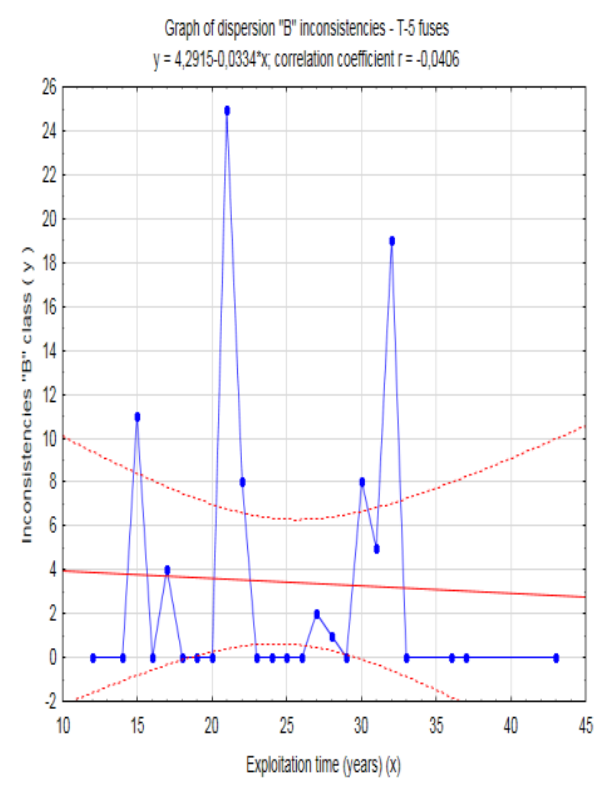

Fig. 14 Inconsistencies of B class in the dependence from exploitation time and regression line describing this dependence for T-5 fuses.

\section{Exploitation time and dynamic diagnostic decisions}

In the aim of exact and detailed statistical analysis, analysis of undertaken diagnostic decisions after conducted dynamic tests that is after shooting tests are presented. The requirement of execution range dynamic tests is dictated to a necessity final test cycle for tested fuse lots in compliance with binding test methodology [1] and necessity undertake final decision.

Dynamic shooting tests have on aim to define degree of the loss battle properties and establish influence of detected inconsistencies during laboratory tests on the safety and reliability operating of cartridges and their elements during normal battle shooting. 
Verification postdiagnostic decisions tested of artillery fuses

Weryfikacja decyzji podiagnostycznych badanych zapalników artyleryjskich

On the following graphs dependences of fraction of positive decisions in relations to exploitation time are presented. As the positive decision, in this case „Z" decision - use in the first order, which can be undertaken after conducted shooting tests. However, possible decisions that is „BPS” decision - shooting test again and „W" decision - withdraw from exploitation accepted as negative decisions.

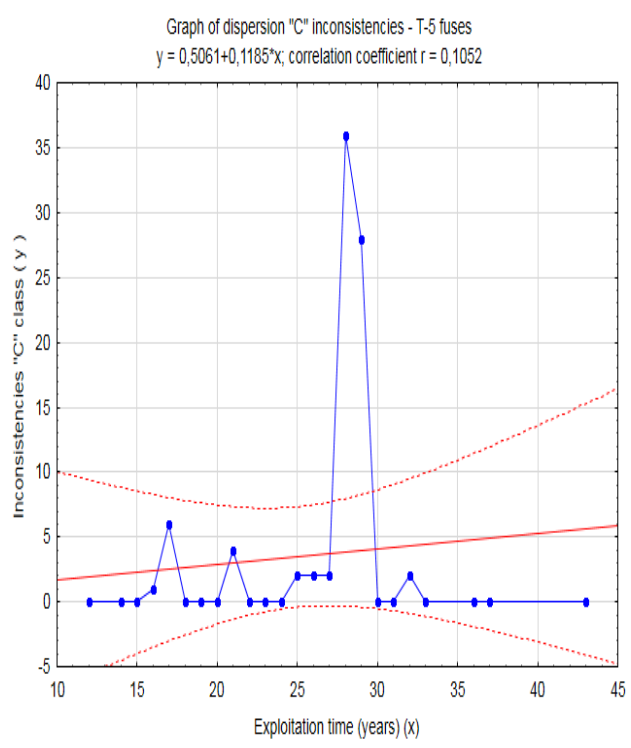

Fig. 15 Inconsistencies of $C$ class in the dependence from exploitation time and regression line describing this dependence for $T$-5 fuses.

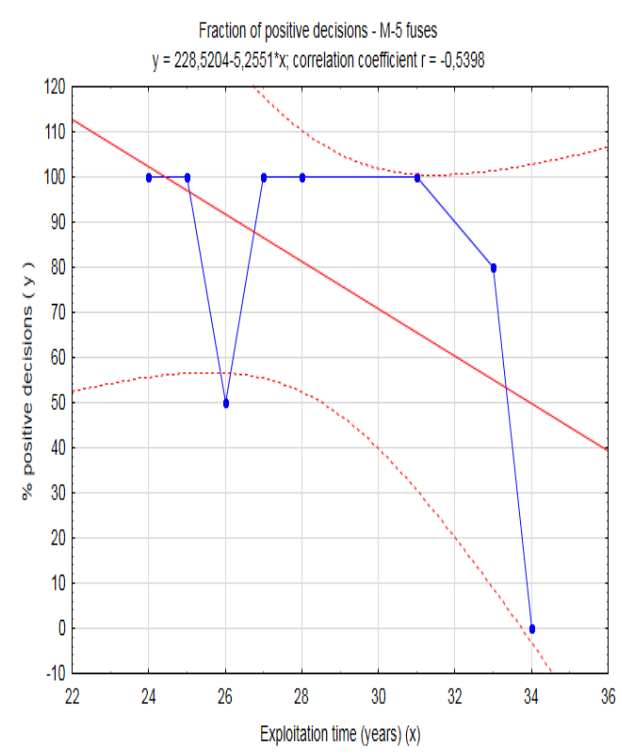

Fig. 16 Graph of dependence betweer. the exploitation time until the moment of test and fraction positive decisions after shooting test and regression line for M-5 fuses.

Exploitation time to the moment of shooting test is taken as an independent variable, and as dependent variable taken fraction of positive decisions. On figures $16 \div 19$ a fraction of positive decisions in dependence from exploitation time is shown, for undertaken decisions after conducted shooting tests. Such graph was not presented for T-5 fuse types, because only three fuse lots were tested by shooting. Results of shooting tests samples coming from stored fuse lots following types: MD-8, M-5, MG-37 and MG-57 were subjected in the statistical analysis.

In the case of M-5, MD-8 and MG-57 fuse types we see decreasing tendency, that comes together with passage of exploitation time, follows the positive decisions fractions fall. Coefficients values of Pearson's linear correlation are $r=-0,5398$ for M-5 fuses type (fig. 16), $r=-0,1451$ for MD-8 fuses type (fig. 17) and $r=-0,2251$ for MG-57 fuses type (fig. 19). However, in the case of MG-37 fuses increasing tendency is visible. The coefficient value of linear correlation is $r=0,2162$ (fig.18), that is together with passage exploitation time follows the growth fraction of positive decisions. 


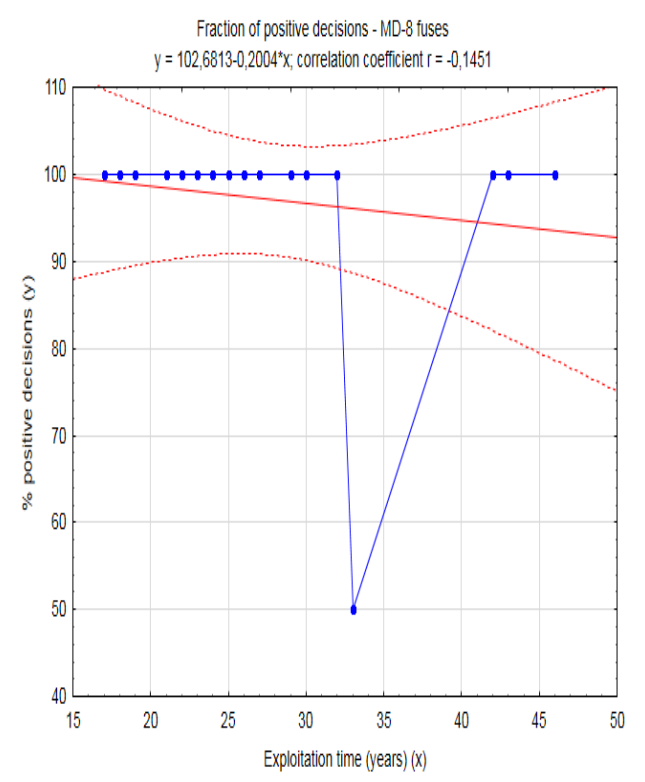

Fig. 17 Graph of dependence between the exploitation time until the moment of test and fraction positive decisions after shooting test and regression line for MD-8 fuses.

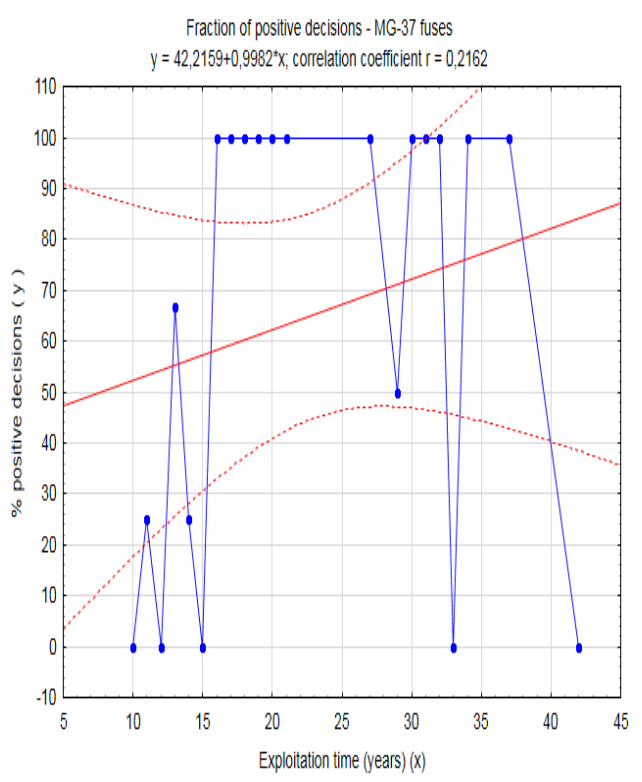

Fig. 18 Graph of dependence between the exploitation time until the moment of test and fraction positive decisions after shooting test and regression line for MG-37 fuses.

\section{Inconsistencies in dynamic tests in the dependence of exploitation time}

Analyses of inconsistencies, which appeared during dynamic shooting tests is also executed in the article. On following figures $20 \div 25$ dependences dispersion of inconsistencies individual classes in relations from exploitation time are presented. Not all classes of inconsistencies were analysed from the attention on too little quantity which appeared during shooting tests.

Only inconsistencies of B class (fig. 20) in case of M-5 fuse types were analysed. It is visible, that inconsistencies of this class have increasing tendency, that comes together with passage exploitation time inconsistencies of this class grow. The coefficient value of linear correlation is $r=0,5727$.

The similar situation is in the case of MD-8 fuse types. For these fuses only one class of inconsistencies, namely inconsistencies of A class (fig. 21) was analysed. In this case, inconsistencies tendency of A class has a growing character, but this is significantly weaker, because of coefficient of linear correlation is only $r=0,1827$. For MG-37 fuse types all classes of inconsistencies were analysed. This was most representative fuse. All three classes of inconsistencies that is A, B and C show decreasing tendency i. e. together with passage exploitation time for these fuse lots, values inconsistencies of individual classes show the decrease.

Coefficients of linear correlation are $\mathrm{r}=-0,3317$ for inconsistencies of A class (fig. 22), $r=-0,49$ for inconsistencies of $B$ class (fig. 23) and $r=-0,4001$ for inconsistencies of C class (fig. 24). 
Verification postdiagnostic decisions tested of artillery fuses Weryfikacja decyzji podiagnostycznych badanych zapalników artyleryjskich

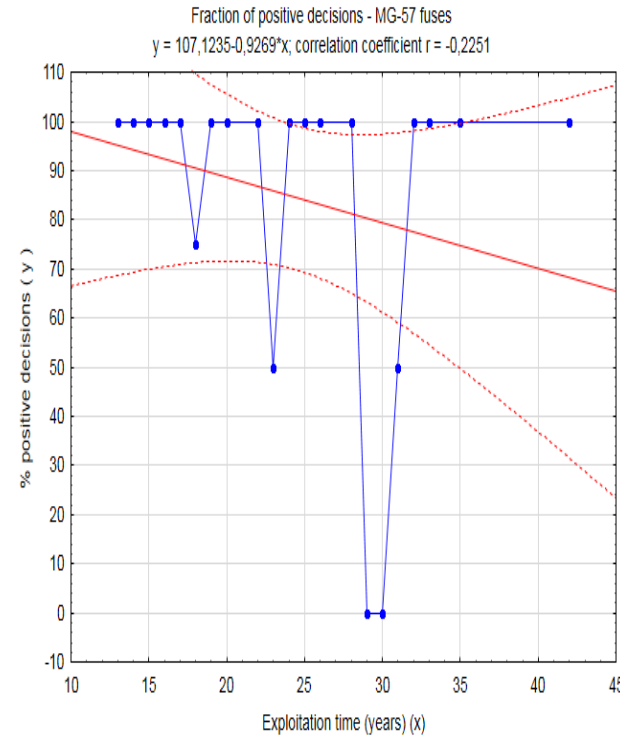

Fig. 19 Graph of dependence between the exploitation time until the moment of test and fraction positive decisions after shooting test and regression line for MG-57 fuses.

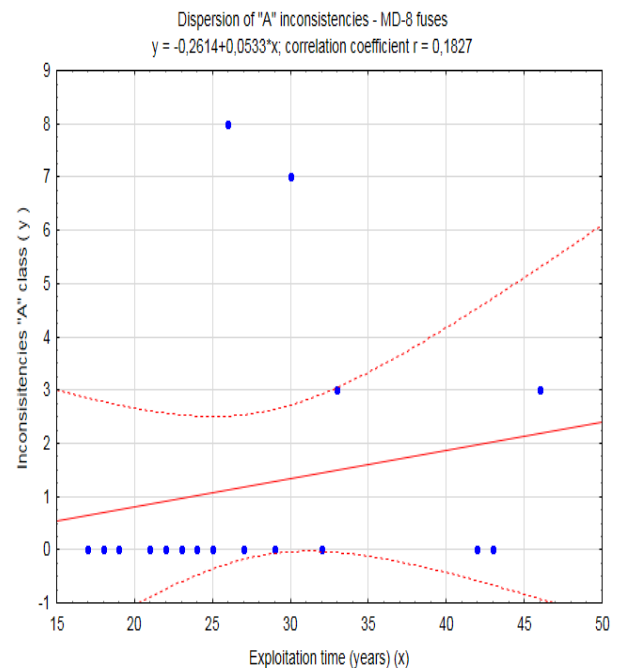

Fig. 21 Inconsistencies of A class after shooting test in the dependence from exploitation time and regression line describing this dependence for MD-8 fuses.

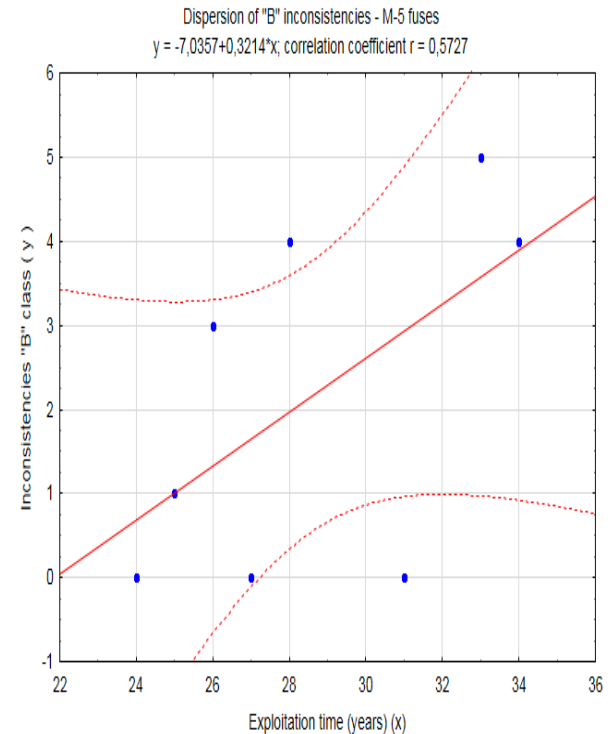

Fig. 20 Inconsistencies of B class after shooting test in the dependence from exploitation time and regression line describing this dependence for M-5 fuses.

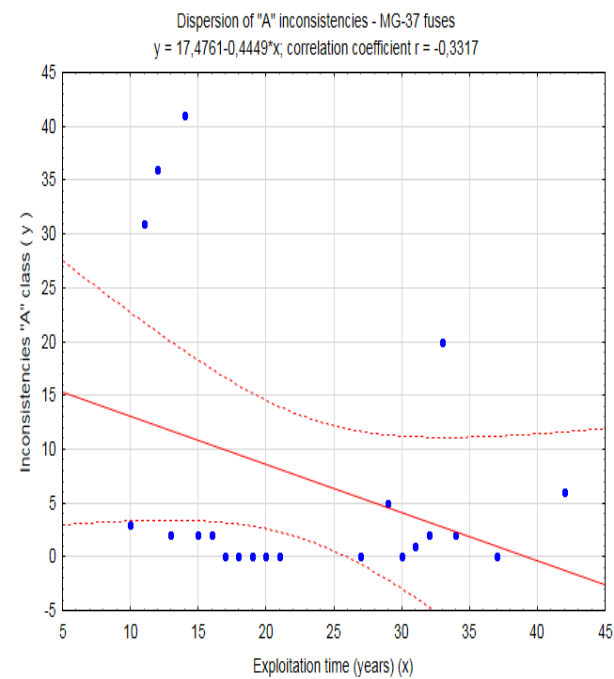

Fig. 22 Inconsistencies of A class after shooting test in the dependence from exploitation time and regression line describing this dependence for MG-37fuses. 
In the case of MG-57 fuse types only inconsistencies of A class (fig. 25) were analysed. They have also decreasing tendency that comes together with passage of exploitation time their quantity falls. The coefficient value of linear correlation is $\mathrm{r}=-0,1647$.

\section{Conclusions}

In the article detailed statistical analysis artillery M-5, MD-8, MG-37, MG-57 and T-5 fuse types were presented. The purpose of this article was to show the changes in aging tendency setting in analysed fuses on the basis test results obtained in laboratory tests and in dynamic shooting tests. A determinant of these changes were obtained postdiagnostic decisions and quantity of inconsistencies ascertained during these diagnostic tests. An additional purpose of this article was also the verification of undertaken diagnostic decisions shooting test under the angle possibilities modification of evaluation module functioning in the test methodology of artillery fuses.

The analysis dependence of fraction shooting decisions in relations to exploitation time showed that this fraction has different character in dependence from consider fuse types. Different change tendencies is visible, in case of analysed M-5, MD-8 and T-5 fuses this is increasing tendency, however in case MG-37 and MG-57 fuse types follows the decrease of fraction of shooting decisions together with passage exploitation time.

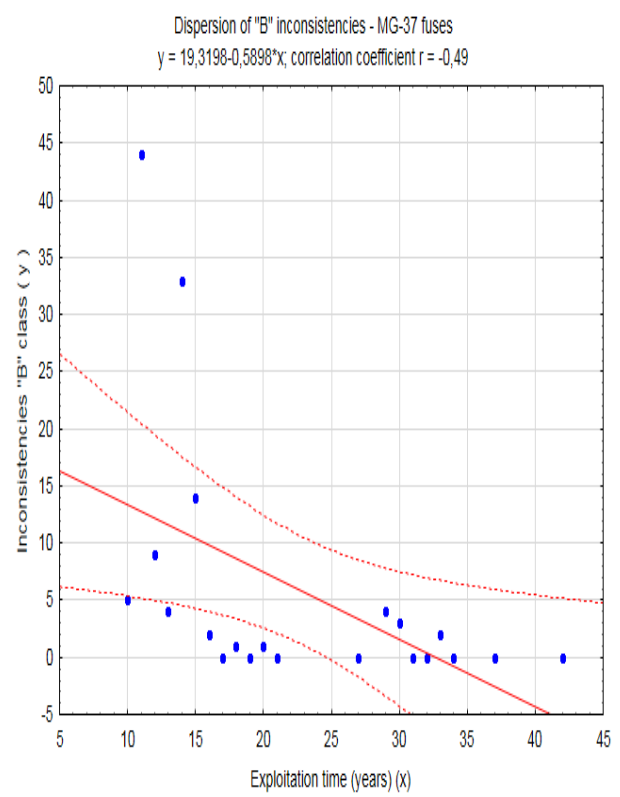

Fig. 23 Inconsistencies of B class after shooting test in the dependence from exploitation time and regression line describing this dependence for MG-37 fuses.

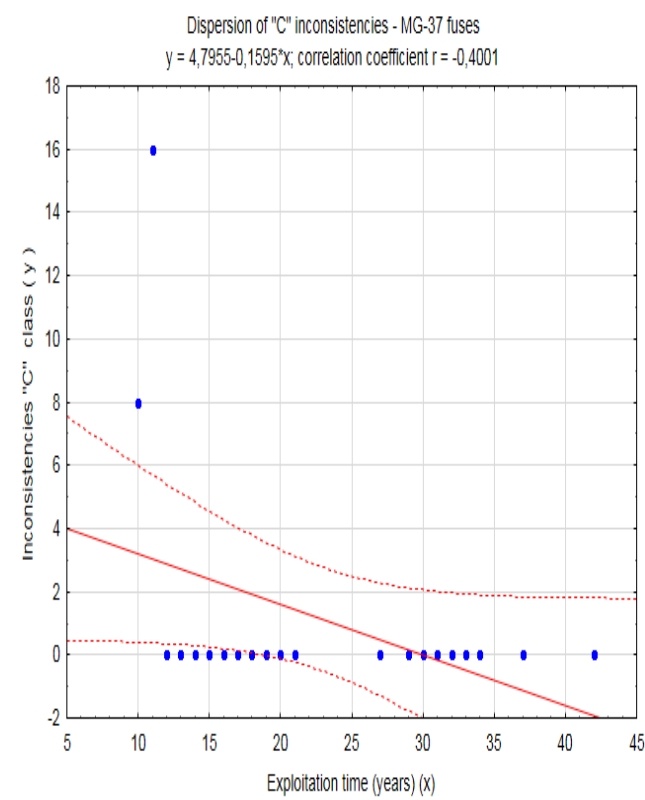

Fig. 24 Inconsistencies of C class after shooting test in the dependence from exploitation time and regression line describing this dependence for MG-37 fuses. 


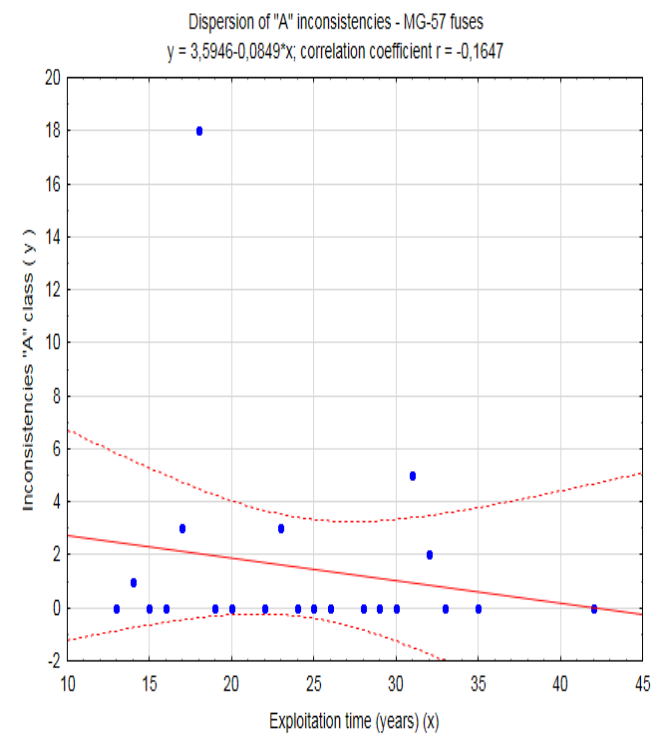

Fig.25 Inconsistencies of A class after shooting test in the dependence from exploitation time and regression line describing this dependence for $M G-57$ fuses.

In the case of analysis dispersion of inconsistencies different classes in relations from exploitation time, which were detected after laboratory tests, different character of these changes is also visible. The M-5 fuse types show decreasing tendency for inconsistencies of A and B classes, however inconsistencies of C class were not considered. The MD-8 fuse types also show decreasing tendency in the case of inconsistencies of $\mathrm{A}$ and $\mathrm{C}$, however in the case of $\mathrm{B}$ class occurrence practically remain on constant level. In the case MG-37 and MG-57 fuse types analysed only inconsistencies of $\mathrm{C}$ class, which has decreasing character of changes. Remaining classes of inconsistencies did not appear in the quantity indicated to conducting of statistical analysis. T-5 fuse types were considered in three classes of inconsistencies. In case of inconsistencies of A and B classes we have to deal with the fall quantity of inconsistencies together with passage exploitation time, however inconsistencies of $\mathrm{C}$ class showed light growth their quantity.

The analysis dependence of fraction undertaken positive decisions after conducted shooting tests in relation to exploitation time, was not considered for T-5 fuse types, due to only three shootings of this fuse type. However in case M-5, MD-8 and MG-57 fuse types decreasing tendency fraction of positive decisions is visible, only MG-37 fuse types showed increasing tendency.

In the case of analysis dispersion of inconsistencies in individual classes after conducted dynamic shooting tests in dependence from exploitation time, only some classes of inconsistencies due to the too little quantity their occurrence were considered. For M-5 fuse types analysed only inconsistencies of B class, which have express growing character of changes. For MD- 8 fuse types also only one class of inconsistencies was considered, namely inconsistencies of A class, which also have growing character of changes. 
The next fuse with analysed only one class of inconsistencies were MG-57 fuses, in which inconsistencies of A class have decreasing tendency. Only MG-37 fuse types were considered in all classes of inconsistencies. In all classes of inconsistencies of $\mathrm{A}, \mathrm{B}$ and $\mathrm{C}$ we see express decreasing tendency together with passage exploitation time.

Summing up we can affirm that conducted diagnostic tests analysed in this article of chosen artillery fuse types, caused undertake in compliance with binding test methodology, decision about dynamic shooting test these fuse lots. However, as result of conducted this exact statistical analysis, can offer conclusions which can suggest, that shooting tests can be skip in evaluation procedure of laboratory tests. Undertaken diagnostic decisions after conducted shooting tests, confirm assumption that tested fuse lots, were in good technical state. About this fact testifies undertaken positive diagnostic decisions after dynamic tests that is decisions "Z" - use in the first order.

Based on this analysis, it belonged to wonder over the change of evaluation module after conducted laboratory tests. The author of this article advances such possibility, having knowledge from other artillery fuse types and other elements of ammunition area tests conducted. A very important argument to this is fact, that dynamic shooting tests are expensive tests in their execution, exceeding costly significantly laboratory tests. The modification of evaluation system will not negatively influence the quality of conducted diagnostic tests, yet will not negatively influence on correct evaluation of prediction process tested ammunition elements which are artillery fuses. Therefore is indicated, due to costs, the change of this evaluation module and consider these changes in the new methodology tests according to author.

A good solution in evaluation author of article, would be a replacement of "BS" decision - shooting test in evaluation module during laboratory tests, by "PS" decision - to test according special programme. Such modification will not influence on reduction defining correctness prediction of safety exploitation periods for tested artillery fuses. It also will not influence on reliability operation of these fuses. It will cause the possibility of further safety exploitation fuse lot stored in resources of Polish Army. To the moment of unfinished cycle test, every tested fuse lot is in so called suspension and we can do nothing with this lot. From the author's information it results that on shooting tests expects over 100 lots from among fuse types analysed in this article. Even undertaken decision about utilization given lot, before final cycle test, can cause some suggestions for control offices about damage executed among military property. Due to this, to reduce quantity fuse lots suspended in exploitation, the modification of evaluation module according author's proposal presented in this article is indicated. 
Verification postdiagnostic decisions tested of artillery fuses Weryfikacja decyzji podiagnostycznych badanych zapalników artyleryjskich

\section{Literature}

[1] The group work - The methodology of diagnostic tests of ammunition - Index N-5001b - 1985, the archive of Military Institute of Armament Technology (MIAT);

[2] The handbook - Ammunition of Land Forces - The Ministry of National Defense - 1985;

[3] Statistica 10 - Statsoft Poland 2010 - computer software;

[4] Reports from tests of ammunition - the archive of MIAT;

[5] Cards of laboratory tests of fuses - the archive of MIAT;

[6] Cards of shooting tests of fuses - the archive of MIAT.

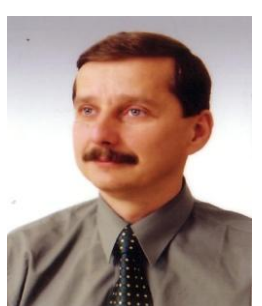

D. Sc. Eng. Dariusz Ampula, graduated Military Technical Academy in the area of the Ground Armament Systems. He became the scientifically - test worker at Military Institute of Armament Technology in Zielonka after holding of one year professional practice. The degree scientific of doctor he obtained in 2006 in Air Force Institute of Technology. The author and coauthor of works from the area technical diagnostics and reliability of working land ammunition. In his analytical analysis he focuses on the problems of prediction process tested elements of land ammunition. 


\section{WERYFIKACJA DECYZJI PODIAGNOSTYCZNYCH BADANYCH ZAPALNIKÓW ARTYLERYJSKICH}

\section{Wprowadzenie}

Zapalniki artyleryjskie [2] są to precyzyjne elementy amunicji przeznaczone do inicjowania działania pocisków $\mathrm{w}$ celu lub na torze lotu $\mathrm{w}$ czasie założonym konstrukcyjnie lub zaprogramowanym przed wystrzałem. Tak jak inne elementy amunicji, podlegają one systematycznym badaniom diagnostycznym. Pierwszym etapem badań są przeprowadzane badania laboratoryjne oczywiście zgodnie z obowiązującą metodyką badawczą [1]. Zakres tych badań oraz ich częstotliwość określa wyżej wskazana metodyka badawcza. W wyniku tych badań, badana partia zapalników artyleryjskich może być uznana za dobrą i wówczas określony zostaje okres bezpiecznej jej eksploatacji przez kolejnych trzy lub pięć lat (decyzja B3 lub B5). Może także być podjęta decyzja negatywna, która stwierdza, że na skutek stwierdzonych podczas badań niezgodności partia ta powinna być wycofana z użytkowania, ze względu na jej bezpieczeństwo eksploatacji (decyzja W). Może być również podjęta decyzja o niezakończeniu bieżącego cyklu badawczego i partię tą należy badać dynamicznie strzelaniem (decyzja BS). Badanie to polega na przeprowadzeniu badań dynamicznych, których zakres, warunki oraz możliwe do podjęcia decyzje diagnostyczne po tych badaniach, określa aktualna metodyka badawcza.

W artykule tym autor podejmuje próbę przeprowadzenia statystycznej analizy wybranych typów badanych zapalników artyleryjskich. Celem więc artykułu będzie weryfikacja oraz ocena statystyczna podjętych decyzji badać strzelaniem po przeprowadzonych badaniach laboratoryjnych oraz wnikliwa analiza tych wyników badań, pokazująca różne rodzaje niezgodności jakie zostały zdiagnozowane podczas tych badań laboratoryjnych. Wykonano także analizę decyzji diagnostycznych podjętych po przeprowadzonych badaniach dynamicznych strzelaniem łącznie $\mathrm{z}$ analizą różnych rodzajów niezgodności jakie wystąpiły podczas tych badań.

Analizie statystycznej poddano zapalniki typu M-5, MD-8, MG-37, T-5 oraz MG-57. Były one stosowane w $120 \mathrm{~mm}$ nabojach moździerzowych, $85 \mathrm{~mm}$ nabojach przeciwpancerno-smugowych, $37 \mathrm{~mm}$ nabojach odłamkowo-smugowych, w $57 \mathrm{~mm}$ nabojach odłamkowo-smugowych oraz w $85 \mathrm{~mm}$ przeciwlotniczych nabojach odłamkowych. Zbiory partii zapalników tych typów nie były wcześniej analizowane. Wykonana analiza obejmuje wszystkie dotychczasowe wyniki badań laboratoryjnych oraz dynamicznych badań strzelaniem zapalników jakie zostały wykonane do końca 2010 roku. Późniejsze badania nie były rozpatrywane z racji zmiany metodyki badawczej. Moduł ocenowy wyników badań w nowej metodyce badawczej nie uległ zmianie, dlatego też autor podjął również próbę $\mathrm{w}$ tym artykule modyfikacji tego modułu. 
Verification postdiagnostic decisions tested of artillery fuses

Weryfikacja decyzji podiagnostycznych badanych zapalników artyleryjskich

\section{Cechy zapalników}

Głównymi cechami eksploatacyjnymi według [1] jakimi powinny się charakteryzować zapalniki to ogólne: bezpieczeństwo, niezawodność działania i trwałość tj. odporność na warunki występujące podczas tej eksploatacji. Szczegółowo to: bezpieczeństwo zagwarantowane podczas produkcji detali i zespołów, montażu, kontroli i badań odbiorczych oraz podczas transportu. $\mathrm{W}$ procesie eksploatacji takimi cechami są bezpieczeństwo: podczas strzelań, długoletniego przechowywania, konserwacji, regulacji, napraw, załadunków, rozładunków i przemieszczeń różnymi środkami transportu lądowego, wodnego i powietrznego.

Badane cechy zapalników według [1] podzielono na pięć klas ważności: A, B, C, D i E. Klasy C, D i E charakteryzują bezpieczeństwo i niezawodność działania, natomiast klasy A i B charakteryzują stopień zaawansowania procesu naturalnego starzenia.

$\mathrm{W}$ analizie tej nie będą rozważane niezgodności klasy $\mathrm{D}$ i $\mathrm{E}$, ponieważ w momencie ich wystąpienia, badana partia zapalników otrzymuje zgodnie z obowiązującą metodyką badawczą inną decyzję diagnostyczną niż decyzja badać strzelaniem. Niezgodności tego typu po prostu nie wystąpiły podczas wykonywanych sprawdzeń analizowanych partii zapalników. Rozpatrywane więc będą tylko niezgodności klasy A, B i C.

Podjęcie po badaniach laboratoryjnych decyzji badać strzelaniem, dla badanej partii zapalników, uwarunkowane jest wystąpieniem określonej ilości niezgodności klasy A, B lub C. Ilość tych niezgodności zapisana jest $\mathrm{w}$ tabelach oceny w metodyce badawczej dla każdego rodzaju zapalnika oddzielnie. Opracowanie tych tabel oceny, poprzedzone zostało szeregiem analiz statystycznych wykonanych dla badanych typów zapalników.

\section{Analiza badanych zapalników}

Analizie statystycznej poddano wyniki badań laboratoryjnych próbek pochodzących ze składowanych partii zapalników następujących typów: M-5, MD-8, MG-37, MG-57 i T-5.

Wyżej wymienione zbiory próbek, otrzymały podczas badań laboratoryjnych decyzję badać strzelaniem. Badania diagnostyczne zapalników przeprowadzono zgodnie z metodyką badawczą [1]. Celem tej analizy jest także poznanie procesów naturalnego starzenia analizowanych zapalników, określenie wpływu tych procesów na ich wskaźniki jakościowe oraz wyznaczenie bezpiecznych okresów predykcji dla analizowanych typów zapalników.

W praktyce statystycznej badanie wpływu jednego czynnika na inny sprowadza się do badania zależności między tymi czynnikami. W artykule tym, przedstawiono jedynie najistotniejsze zależności, które pokazują wzajemną relację analizowanych wielkości.

Do analizy statystycznej zastosowano zatem metody analizy regresji i korelacji liniowej pozwalające na ocenę i określenie charakteru zależności. 
Wykreślono także dla każdego wykresu, 95\% przedział ufności analizowanych wielkości. Wykorzystano specjalistyczne oprogramowanie statystyczne [3], którego Instytut jest właścicielem. Przeanalizowano i omówiono w artykule jedynie te powstałe wykresy, które są najistotniejsze i w subiektywnej opinii autora artykułu najbardziej znaczące.

\section{Czas eksploatacji a laboratoryjne decyzje diagnostyczne}

Najbardziej ogólnym wskaźnikiem jakości eksploatowanych partii zapalników jest decyzja dotycząca tej partii, podjęta po zbadaniu pochodzącej z niej próbki. Dla celów niniejszej analizy rozpatrywane będą jak już wspomniałem wcześniej tylko podjęte decyzje badać strzelaniem podczas pierwszego badania laboratoryjnego. Decyzje te mówią nam, że badana partia zapalników jest niezdatna do dalszej eksploatacji do czasu zakończenia cyklu badawczego. Aby ten cykl badawczy zakończyć, należy przeprowadzić badania dynamiczne strzelaniem. Po tych badaniach, powinien być zakończony dany cykl badawczy i powinna być podjęta decyzja kończąca. Decyzja ta może być pozytywna, czyli partia ta może być przeznaczona do zużycia w pierwszej kolejności lub może ona być negatywna czyli może być wycofana $\mathrm{z}$ eksploatacji.

W analizie tej nie uwzględniono wyników badań strzelaniem powtórnie, ponieważ decyzja taka wydłuża cykl badawczy. Zatem wyniki tych badań powtórnych, nie są porównywalne bezpośrednio $\mathrm{z}$ wynikami badań strzelaniem i nie tworzą z nimi w opinii autora artykułu zbiorów jednorodnych.

Przyjęto, że jakość całego zbioru partii danego rodzaju zapalników w danej chwili badania może zależeć od okresu eksploatacji poszczególnych partii tego zbioru oraz od decyzji o jakości tych partii podejmowanych $\mathrm{w}$ wyniku badań diagnostycznych. Efektem wpływu tego czasu eksploatacji jest występowanie zmian starzeniowych zapalników, mogących powodować powstawanie niezgodności ze względu na poszczególne ich właściwości.

Przy badaniu charakteru tej zależności przyjęto, że zmienną zależną jest frakcja (procent) podjętych decyzji badać strzelaniem. Frakcja jest zatem stosunkiem liczby podjętych decyzji badać strzelaniem do ogólnej ilości zbadanych partii w danym wieku eksploatacji analizowanych typów zapalników. Jako zmienną niezależną przyjęto czas eksploatacji do chwili danego badania. Czas ten jest liczony w latach jako różnica między rokiem danego badania i rokiem produkcji badanej partii zapalnika.

Na rysunkach $1 \div 5$ przedstawiono frakcje decyzji badać strzelaniem w funkcji czasu eksploatacji. $\mathrm{Na}$ podstawie krzywych łamanych reprezentujących poszczególne typy zapalników można stwierdzić, że wraz ze zmianą czasu eksploatacji występuje tendencja zmiany frakcji decyzji badać strzelaniem.

Przebiegi tych krzywych dla dwóch typów zapalników (MD-8 i T-5) wskazują na istnienie tendencji rosnącej tzn. następuje wzrost frakcji decyzji badać strzelaniem w zależności od czasu eksploatacji. Współczynniki korelacji liniowej wynoszą $\mathrm{r}=0,2107$ dla zapalników MD-8 (rys. 2) oraz r=0,3214 dla zapalników T-5 (rys. 5). 
Verification postdiagnostic decisions tested of artillery fuses

Weryfikacja decyzji podiagnostycznych badanych zapalników artyleryjskich

Wielkości te są dodatnie, więc upływ czasu eksploatacji powoduje powiększenie się frakcji podejmowanych decyzji badać strzelaniem.

Przebiegi kolejnych dwóch typów zapalników (MG-37 i MG-57) pokazują na istnienie tendencji malejącej tzn. następuje spadek frakcji decyzji badać strzelaniem w zależności od czasu eksploatacji. Współczynniki korelacji liniowej Pearsona wynoszą $\mathrm{r}=-0,372$ dla zapalników MG-37 (rys. 3) oraz $\mathrm{r}=-0,4804$ dla zapalników MG-57 (rys. 4). Wielkości te są ujemne czyli upływ czasu eksploatacji powoduje zmniejszenie się frakcji podejmowanych decyzji badać strzelaniem.

W jednym przypadku mamy do czynienia praktycznie ze stałą wartością współczynnika korelacji liniowej wynoszącą $r=0,0063$, która informuje nas o tym, że w miarę upływu czasu eksploatacji, frakcja decyzji badać strzelaniem jest prawie na stałym poziomie (są to zapalniki M-5 rys. 1).

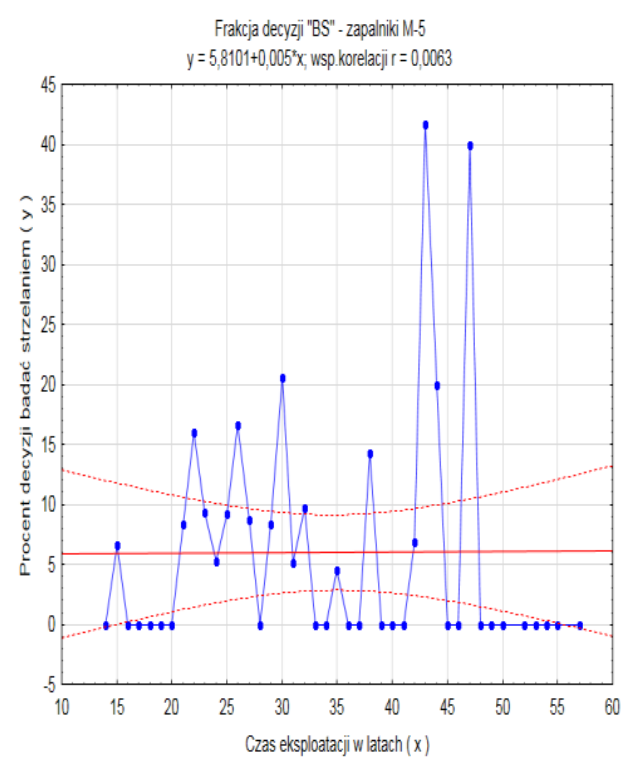

Rys.1 Wykres zależności między czasem eksploatacji i frakcja decyzji badać strzelaniem oraz linia regresji opisujaca ta zależność dla zapalników $M-5$.

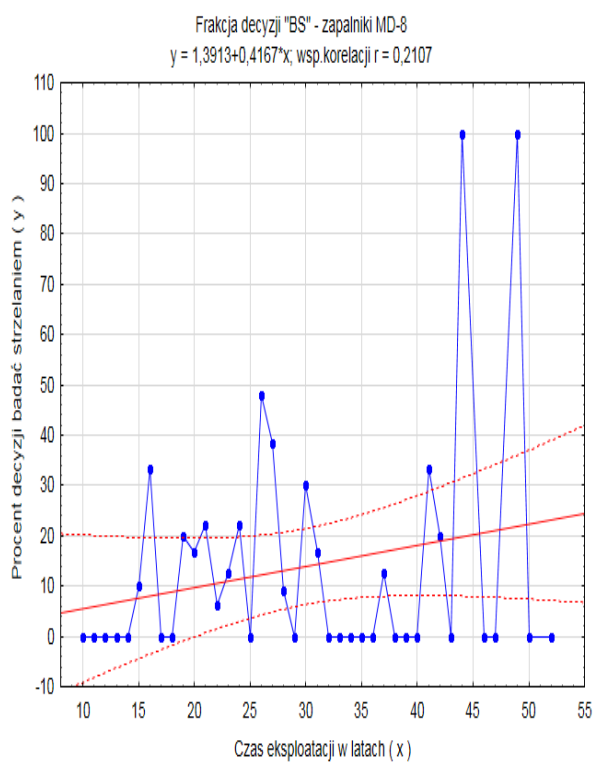

Rys.2 Wykres zależności między czasem eksploatacji i frakcja decyzji badać strzelaniem oraz linia regresji opisująca ta zależność dla zapalników $M D-8$.

\section{Niezgodności $w$ badaniach laboratoryjnych $w$ zależności od czasu eksploatacji}

Kolejnym elementem analizy będzie przedstawienie zależności rozrzutu niezgodności należących do poszczególnych klas niezgodności od czasu eksploatacji badanych partii zapalników. 


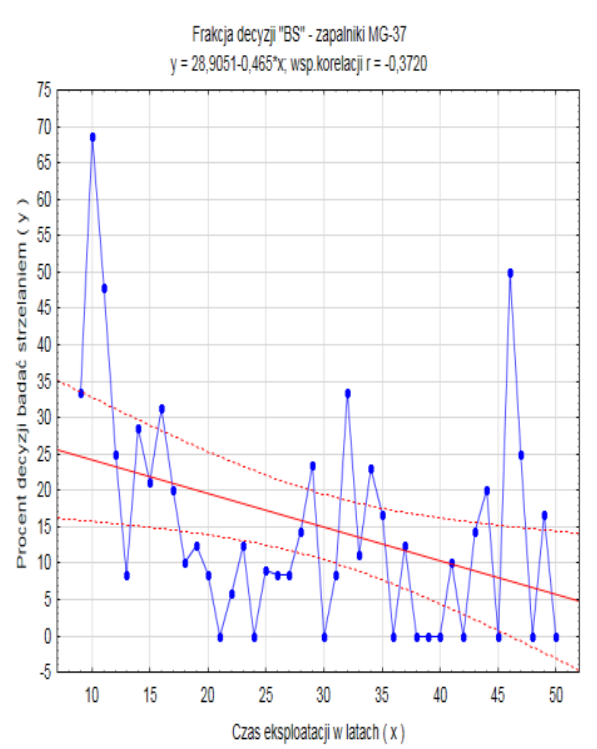

Rys. 3 Wykres zależności między czasem eksploatacji i frakcja decyzji badać strzelaniem oraz linia regresji opisująca ta zależność dla zapalników $M G-37$

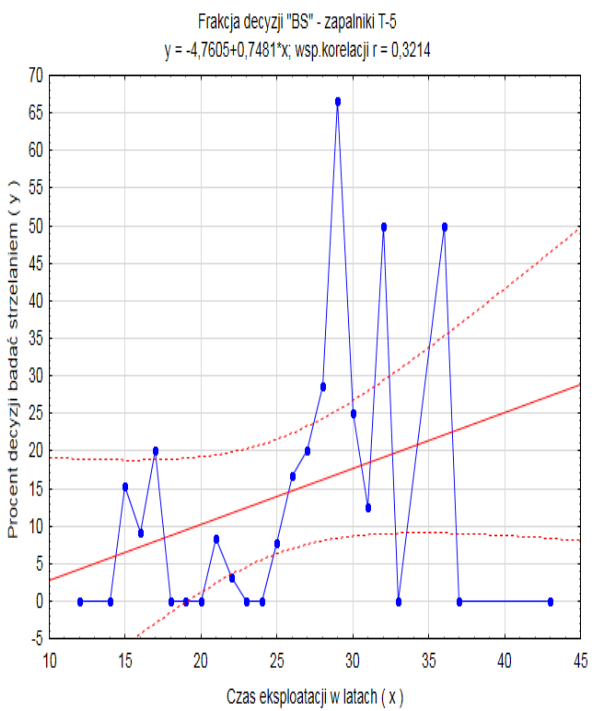

Rys. 5 Wykres zależności między czasem eksploatacji i frakcja decyzji badać strzelaniem oraz linia regresji opisujaca ta zależność dla zapalników T-5.

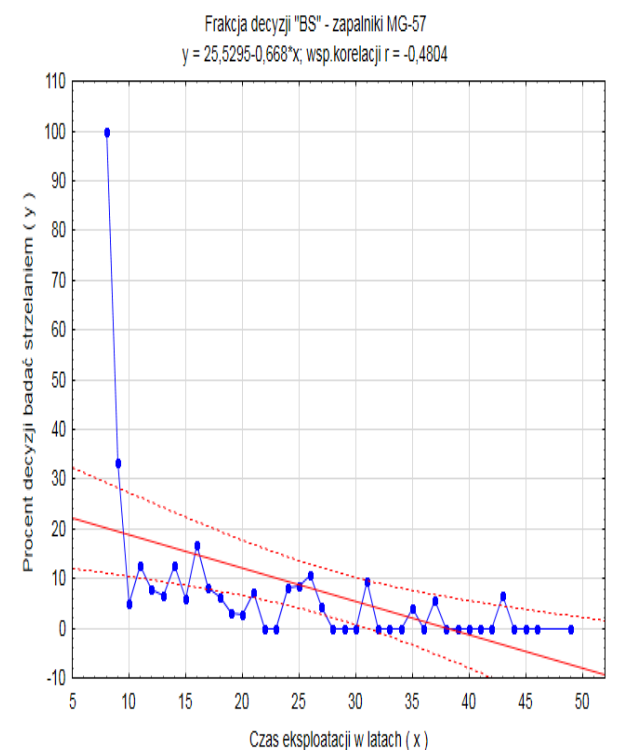

Rys. 4 Wykres zależności między czasem eksploatacji i frakcja decyzji badać strzelaniem oraz linia regresji opisujaca ta zależność dla zapalników $M G-57$

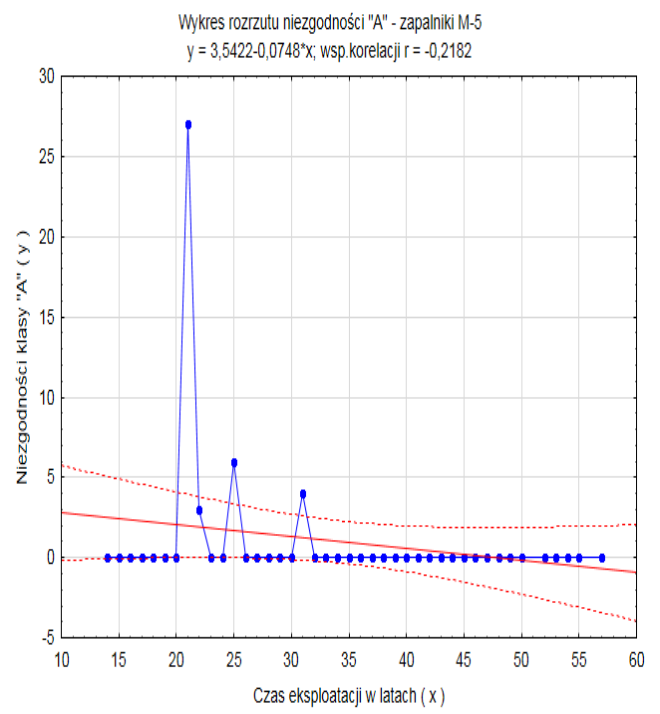

Rys. 6 Niezgodności klasy A $w$ zależności od czasu eksploatacji oraz linia regresji opisujaca ta zależność dla zapalników M-5. 
Verification postdiagnostic decisions tested of artillery fuses

Weryfikacja decyzji podiagnostycznych badanych zapalników artyleryjskich

Jako zmienną niezależną przyjęto więc czas eksploatacji do chwili badania, natomiast jako zmienną zależną przyjęto ilości niezgodności w poszczególnych badanych klasach. Na rysunkach $6 \div 15$ przedstawiono rozrzut niezgodności poszczególnych klas dla zapalników analizowanych w tym artykule. Nie wszystkie klasy niezgodności zostały przedstawione na załączonych wykresach ze względu na małe ilości niezgodności jakie wystąpiły podczas badań laboratoryjnych.

Na rysunkach 6 i 7 przedstawiono wykresy zależności pomiędzy niezgodnościami klasy A i B w funkcji czasu eksploatacji dla zapalników typu M-5. W obu przypadkach widzimy tendencję malejącą, czyli wraz ze wzrostem czasu eksploatacji następuję spadek analizowanej klasy niezgodności. Wartości współczynników korelacji liniowej wynoszą $\mathrm{r}=-0,2182$ (rys.6) w przypadku niezgodności klasy A oraz $\mathrm{r}=-0,2331$ (rys. 7) w przypadku niezgodności klasy $\mathrm{B}$. Niezgodności klasy $\mathrm{C}$ nie były rozpatrywane ze względu na zbyt małą ilość stwierdzonych niezgodności tej klasy podczas badań laboratoryjnych.

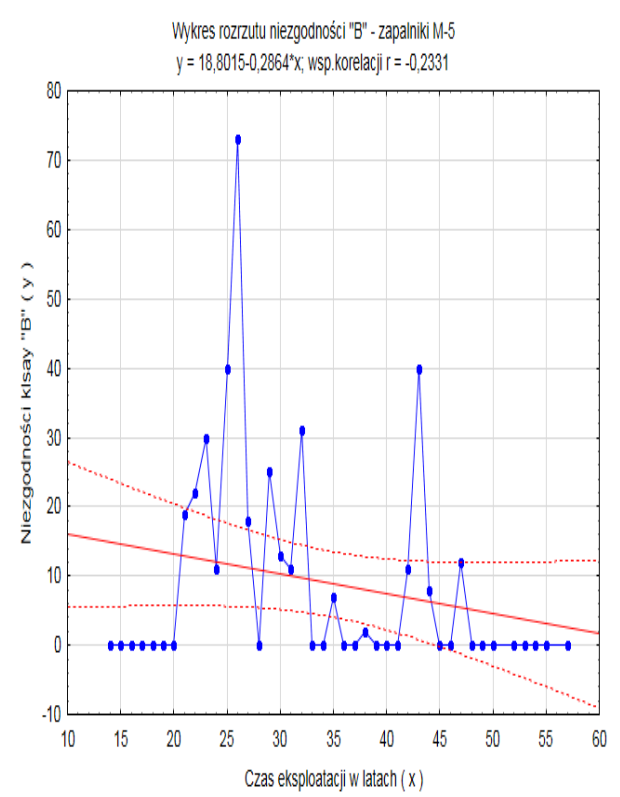

Rys. 7 Niezgodności klasy B

w zależności od czasu eksploatacji oraz linia regresji opisujaca ta

zależność dla zapalników typu M-5

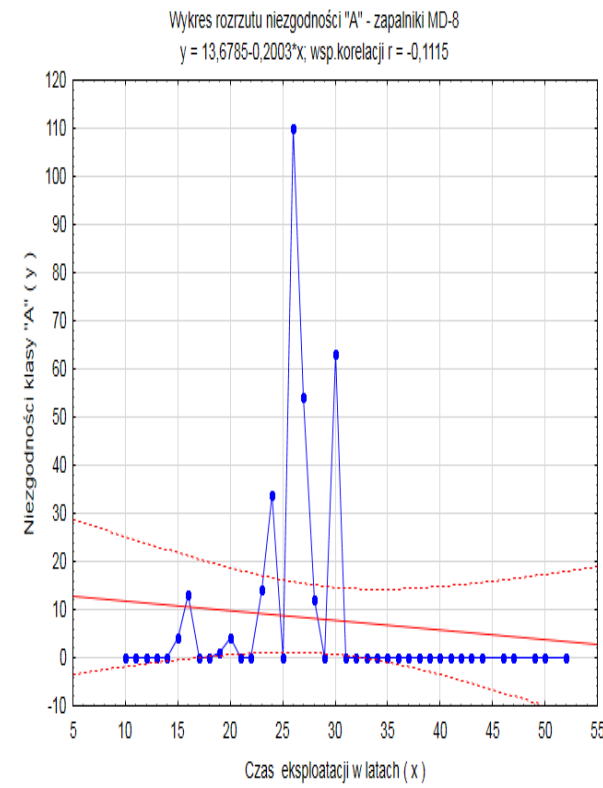

Rys. 8 Niezgodności klasy A $w$ zależności od czasu eksploatacji oraz linia regresji opisujaca ta zależność dla zapalników MD-8

W przypadku zapalników typu MD-8 krzywe przedstawione na rysunkach 8, 9 i 10 wskazują na różną tendencję zmian analizowanych klas niezgodności od czasu eksploatacji. Niezgodności klasy A i C (rys. 8 i 10) wykazują tendencję malejącą. Wartości współczynników korelacji liniowej wynoszą $\mathrm{r}=-0,1115$ dla niezgodności klasy A oraz r=-0,128 dla niezgodności klasy C. Natomiast, niezgodności klasy B wykazują lekką tendencję wzrostową. Wartość współczynnika korelacji liniowej wynosi $r=0,0191$ (rys. 9), czyli niezgodności klasy B są prawie na stałym poziomie w rozpatrywanym okresie czasu. 


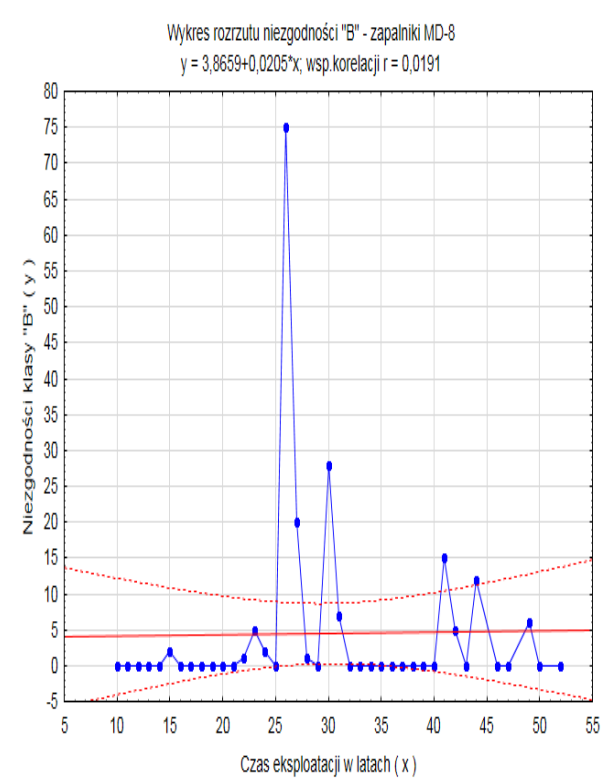

Rys. 9 Niezgodności klasy $B$ $w$ zależności od czasu eksploatacji oraz linia regresji opisujaca ta zależność dla zapalników MD-8

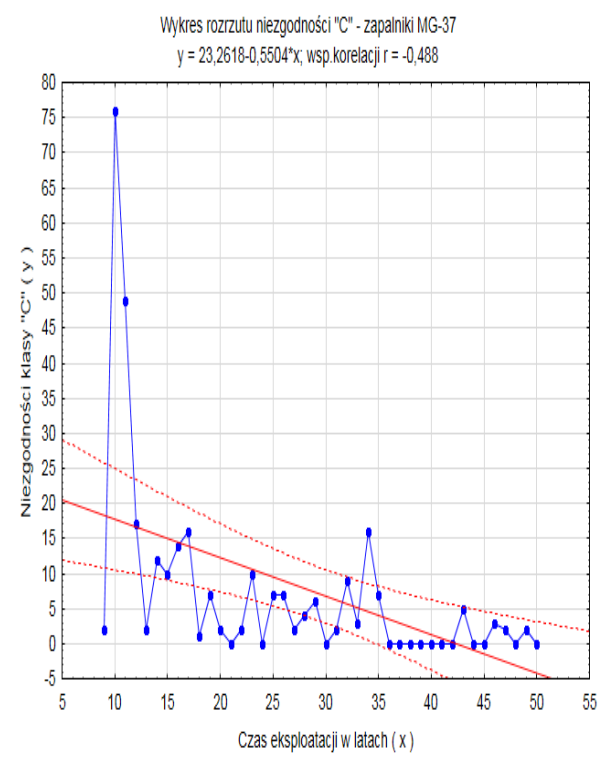

Rys. 11 Niezgodności klasy C w zależności od czasu eksploatacji oraz linia regresji opisujaca ta zależność dla zapalników MG-37

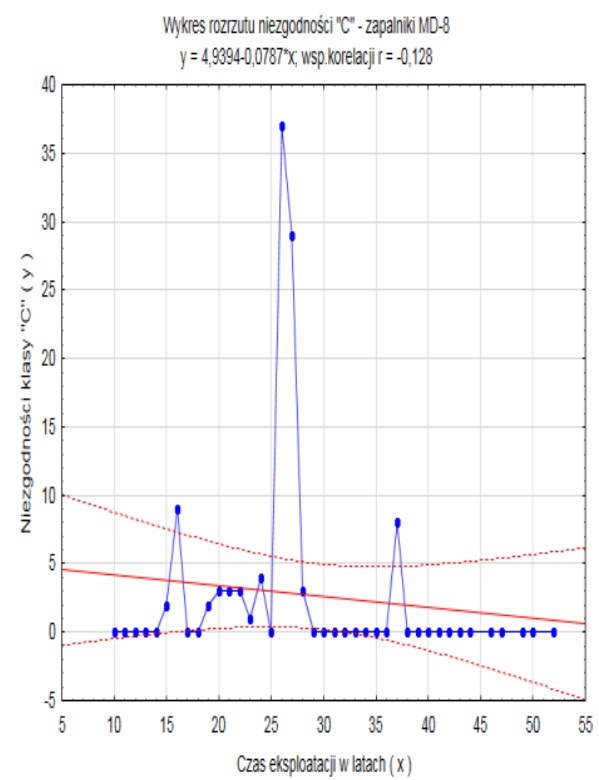

Rys. 10 Niezgodności klasy C $w$ zależności od czasu eksploatacji oraz linia regresji opisujaca ta zależność dla zapalników MD-8

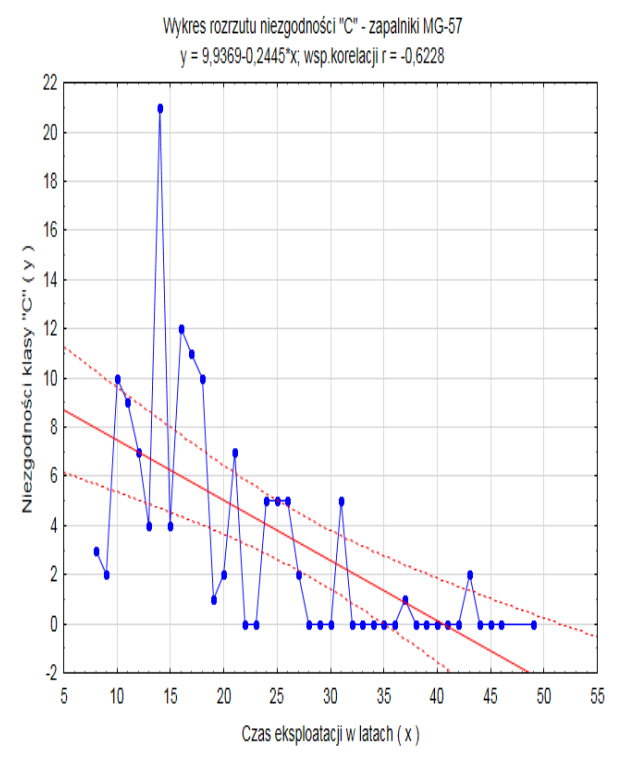

Rys. 12 Niezgodności klasy C w zależności od czasu eksploatacji oraz linia regresji opisujaca ta zależność dla zapalników MG-57 
Verification postdiagnostic decisions tested of artillery fuses

Weryfikacja decyzji podiagnostycznych badanych zapalników artyleryjskich

Na rysunku 11 widzimy przebieg krzywej niezgodności klasy $\mathrm{C}$ w zależności od czasu eksploatacji dla zapalników MG-37. Ujemna wartość współczynnika korelacji liniowej wynosząca $\mathrm{r}=-0,488$ świadczy o wyraźnej tendencji malejącej tej klasy niezgodności w zależności od czasu eksploatacji. Niezgodności klasy A i B, ze względu na ich małą ilość występowania nie były analizowane.

W przypadku zapalników typu MG-57, mamy podobną sytuację. Tylko niezgodności klasy $\mathrm{C}$ mogły być rozpatrywane. $\mathrm{Z}$ wykresu widać (rys. 12), że krzywa ma charakter malejący. Wartość współczynnika korelacji liniowej wynosi $\mathrm{r}=-0,6228$ co świadczy o wyraźnym spadku niezgodności klasy $\mathrm{C} \mathrm{w}$ miarę upływu czasu eksploatacji.

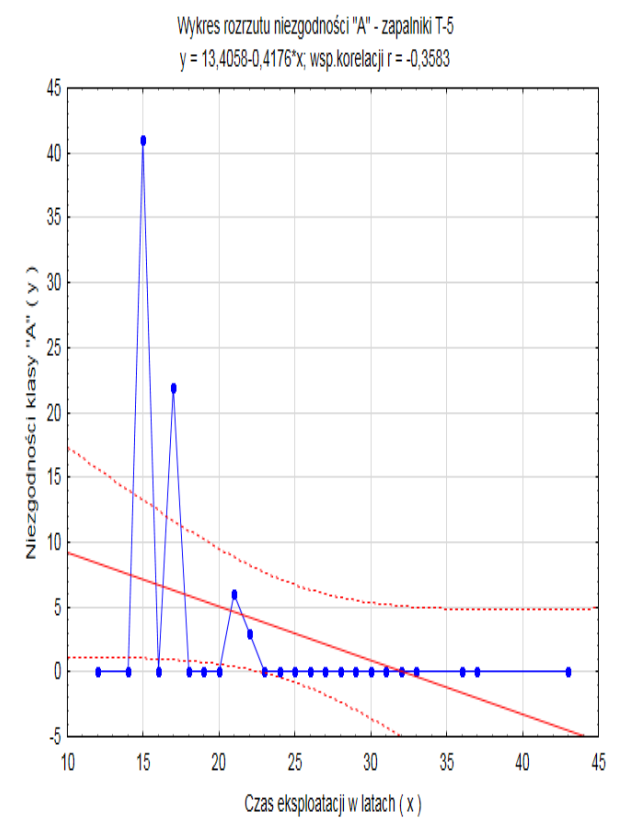

Rys. 13 Niezgodności klasy A $w$ zależności od czasu eksploatacji oraz linia regresji opisujaca ta zależność dla zapalników $T-5$

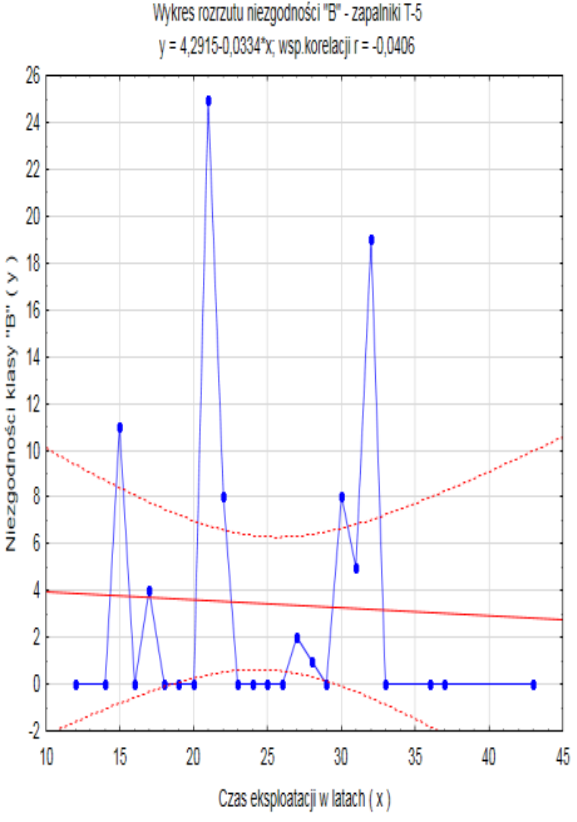

Rys. 14 Niezgodności klasy B w zależności od czasu eksploatacji oraz linia regresji opisujaca ta zależność dla zapalników $T-5$

Na rysunkach $13 \div 15$ przedstawiono wykresy zależności niezgodności klasy A, B i C w relacji od czasu eksploatacji dla zapalników T-5. W przypadku niezgodności klasy A i B widzimy tendencję malejącą, czyli wraz z upływem czasu eksploatacji następuje spadek niezgodności tych klas. Wartości współczynników korelacji liniowej wynoszą dla niezgodności klasy A $r=-0,3583$ (rys. 13) oraz $r=-0,0406$ dla niezgodności klasy $\mathrm{B}$. Natomiast $\mathrm{w}$ przypadku niezgodności klasy $\mathrm{C}$ widzimy tendencję wzrostową. Wartość współczynnika korelacji liniowej wynosi $\mathrm{r}=0,1052$ (rys. 15). 


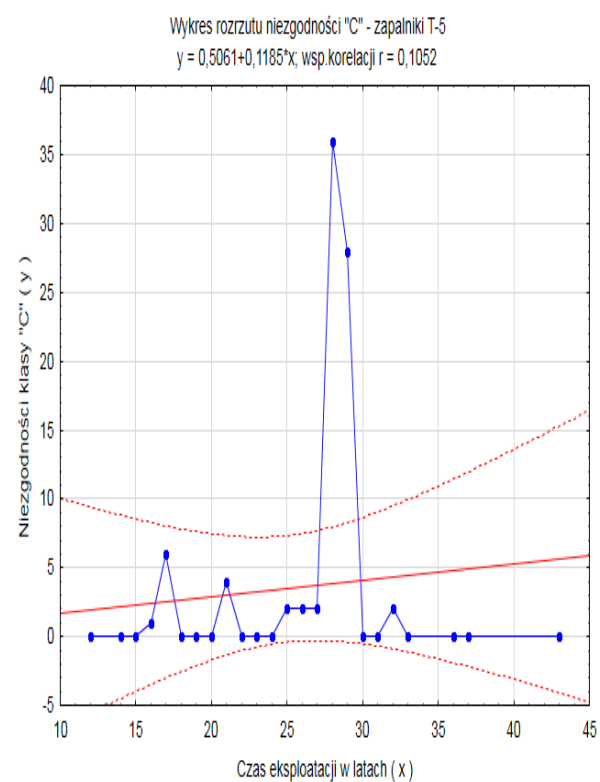

Rys. 15 Niezgodności klasy C w zależności od czasu eksploatacji oraz linia regresji opisujaca ta zależność dla zapalników T-5

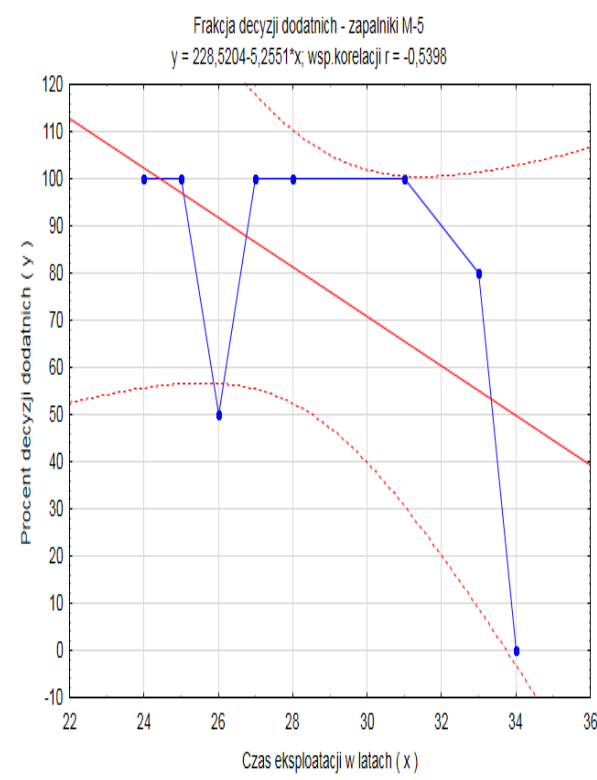

Rys. 16 Wykres zależności między czasem eksploatacji i frakcja decyzji dodatnich po badaniach strzelaniem oraz linia regresji dla zapalników M-5

\section{Czas eksploatacji a dynamiczne decyzje diagnostyczne}

W celu wykonania dokładnej i szczegółowej analizy statystycznej, przedstawiono także analizę podejmowanych decyzji diagnostycznych po przeprowadzonych badaniach dynamicznych czyli po badaniach strzelaniem. Wymóg przeprowadzenia poligonowych badań dynamicznych podyktowany jest koniecznością zamknięcia cyklu badawczego dla badanych partii zapalników zgodnie z obowiązującą metodyką badawczą [1] oraz koniecznością podjęcia decyzji kończącej.

Badania dynamiczne strzelaniem mają na celu określenie stopnia utraty własności bojowych oraz ustalenie wpływu niezgodności wykrytych podczas badań laboratoryjnych na bezpieczeństwo i niezawodność działania naboi lub ich elementów podczas normalnego bojowego strzelania.

Na kolejnych wykresach przedstawiono więc zależności frakcji decyzji dodatnich w relacji do czasu eksploatacji. Jako decyzję dodatnią przyjęto w tym przypadku decyzję $Z$ - zużyć w pierwszej kolejności, która może być podjęta po przeprowadzonych badaniach strzelaniem. Natomiast pozostałe możliwe decyzje czyli decyzję BPS - badać powtórnie strzelaniem oraz decyzję W - wycofać z eksploatacji przyjęto jako decyzje negatywne. 
Verification postdiagnostic decisions tested of artillery fuses

Weryfikacja decyzji podiagnostycznych badanych zapalników artyleryjskich

Jako zmienną niezależną przyjęto czas eksploatacji do chwili badania strzelaniem, a jako zmienną zależną frakcję decyzji dodatnich.

Na rysunkach 16 $\div 19$ przedstawiono frakcję decyzji dodatnich $\mathrm{w}$ zależności od czasu eksploatacji, dla decyzji podjętych po przeprowadzonych badaniach strzelaniem. Nie przedstawiono takiego wykresu dla zapalników typu T-5, ponieważ tylko trzy partie tych zapalników były badane strzelaniem.

Analizie statystycznej poddano więc wyniki badań strzelaniem próbek pochodzących ze składowanych partii zapalników następujących typów: M-5, MD8, MG-37 i MG-57.

W przypadku zapalników typu M-5, MD-8 oraz MG-57 widzimy tendencję malejącą, czyli wraz z upływem czasu eksploatacji, następuje spadek frakcji decyzji dodatnich. Wartości współczynników korelacji liniowej Pearsona wynoszą $\mathrm{r}=-0,5398$ dla zapalników typu M-5 (rys. 16), r=-0,1451 dla zapalników typu MD-8 (rys. 17) oraz $\mathrm{r}=-0,2251$ dla zapalników typu MG-57 (rys. 19). Natomiast w przypadku zapalników MG-37 widać tendencję wzrostową. Wartość współczynnika korelacji liniowej wynosi r=0,2162 (rys.18), czyli wraz z upływem czasu eksploatacji następuje wzrost frakcji decyzji dodatnich.

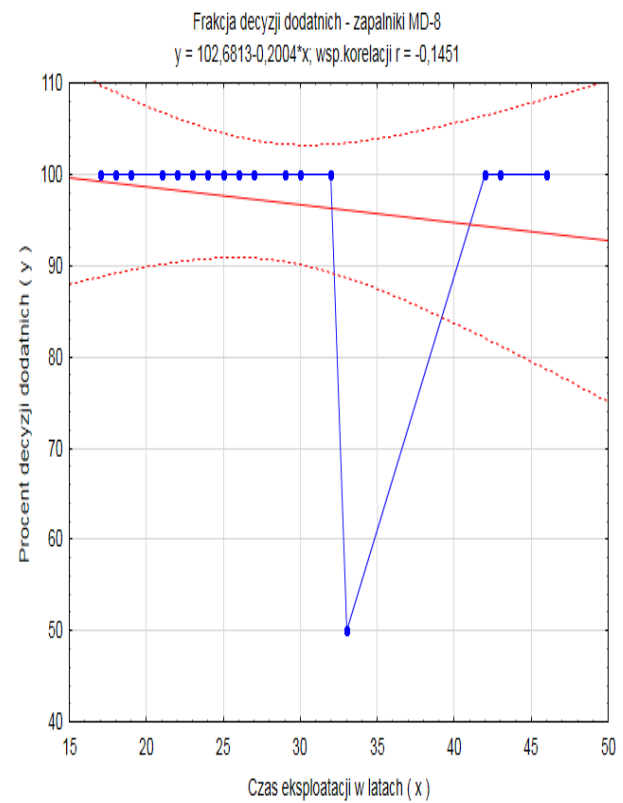

Rys. 17 Wykres zależności między czasem eksploatacji i frakcja decyzji dodatnich po badaniach strzelaniem oraz linia regresji dla zapalników MD-8

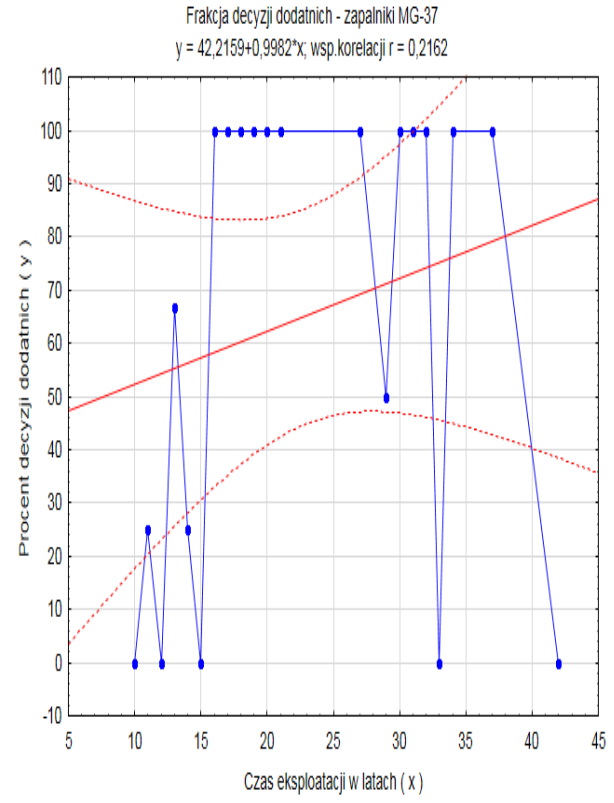

Rys. 18 Wykres zależności między czasem eksploatacji i frakcja decyzji dodatnich po badaniach strzelaniem oraz linia regresji dla $M G-37$ 


\section{Niezgodności $w$ badaniach dynamicznych $w$ zależności od czasu eksploatacji}

W artykule dokonano również analizy niezgodności, które wystapiły podczas badań dynamicznych strzelaniem. Na kolejnych rysunkach $20 \div 25$ przedstawiono zależności rozrzutu niezgodności poszczególnych klas $\mathrm{w}$ relacji do czasu eksploatacji. Nie wszystkie klasy niezgodności były analizowane $\mathrm{z}$ uwagi zbyt małą ich ilość jaka wystąpiła podczas badań strzelaniem.

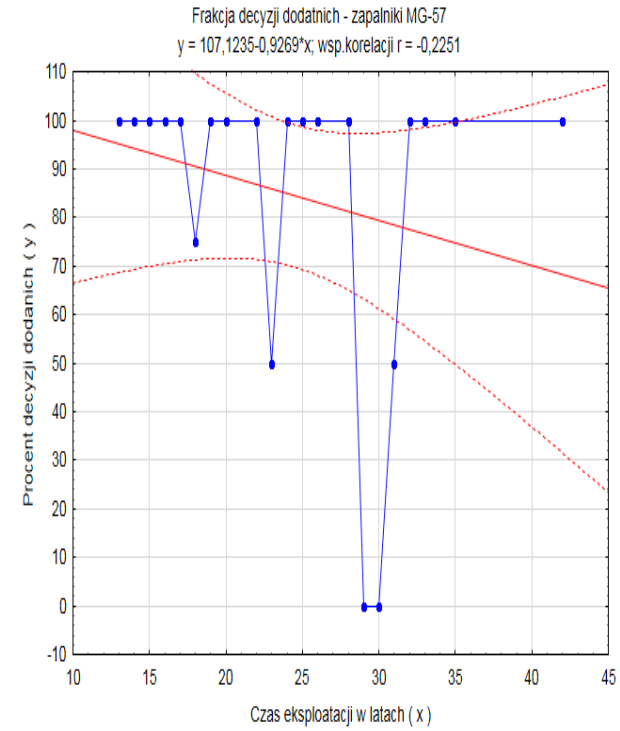

Rys. 19 Wykres zależności między czasem eksploatacji i frakcja decyzji dodatnich po badaniach strzelaniem oraz linia regresji dla zapalników typu $M G-57$

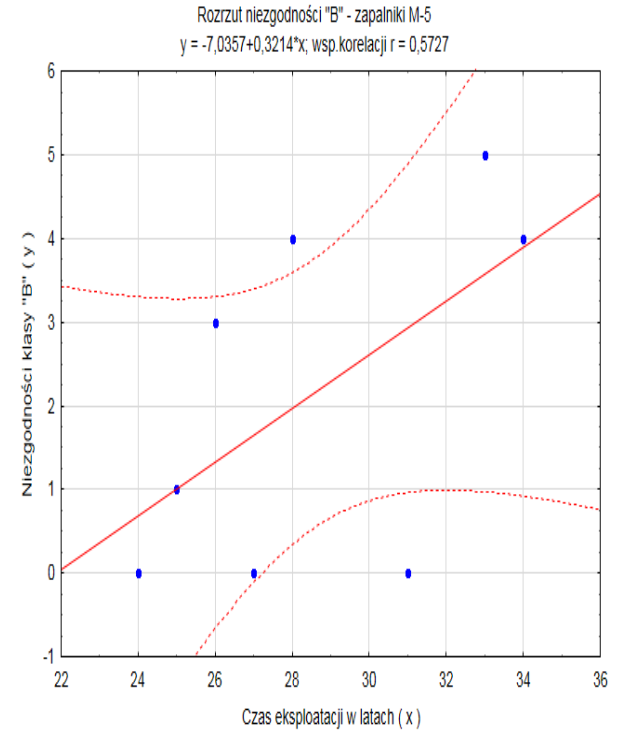

Rys. 20 Niezgodności klasy B po badaniach strzelaniem $w$ zależności od czasu eksploatacji oraz linia regresji opisujaca ta zależność dla zapalników M-5

W przypadku zapalników typu M-5 analizowano tylko niezgodności klasy B (rys.20). Z rysunku widać, że niezgodności tej klasy mają tendencję wzrastającą, czyli wraz z upływem czasu eksploatacji niezgodności tej klasy rosną. Wartość współczynnika korelacji liniowej wynosi $\mathrm{r}=0,5727$.

Podobna sytuacja jest w przypadku zapalników typu MD-8. Dla tych zapalników analizowano także tylko jedną klasę niezgodności, a mianowicie niezgodności klasy A (rys. 21). W tym przypadku, tendencja niezgodności klasy A ma także charakter rosnący, ale jest to znacznie słabsza tendencja, ponieważ współczynnik korelacji liniowej wynosi tylko $\mathrm{r}=0,1827$. Dla zapalników typu MG-37 analizowano wszystkie klasy niezgodności. Był to zapalnik najbardziej reprezentatywny. Wszystkie trzy klasy niezgodności czyli A, B i C wykazują tendencję malejącą tzn. w miarę upływu czasu eksploatacji dla tych partii zapalników, wartości niezgodności poszczególnych klas wykazują spadek. Współczynniki korelacji liniowej wynoszą $r=-0,3317$ dla niezgodności klasy A (rys. 22), $r=-0,49$ dla niezgodności klasy B (rys. 23) oraz $r=-0,4001$ dla niezgodności klasy C (rys. 24). 
Verification postdiagnostic decisions tested of artillery fuses

Weryfikacja decyzji podiagnostycznych badanych zapalników artyleryjskich

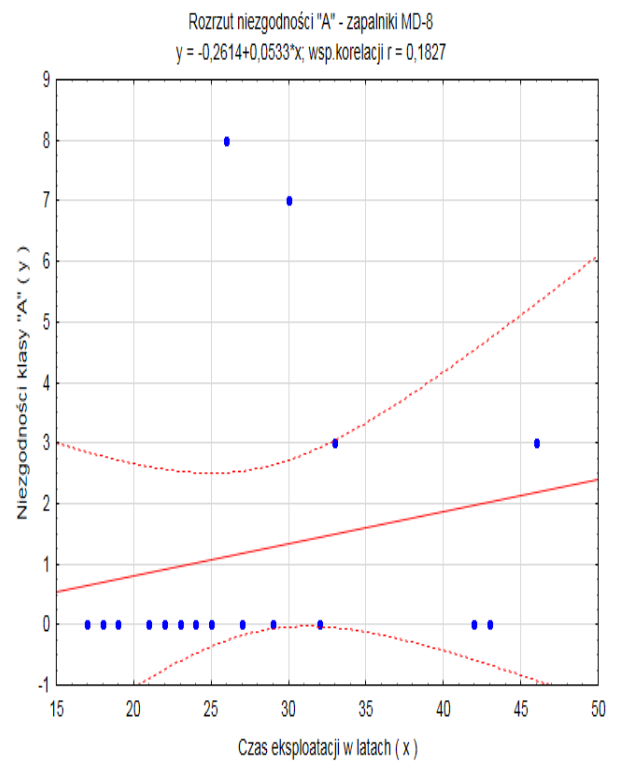

Rys. 21 Niezgodności klasy A po badaniach strzelaniem $w$ zależności od czasu eksploatacji oraz linia regresji opisująca tą zależność dla zapalników $M D-8$

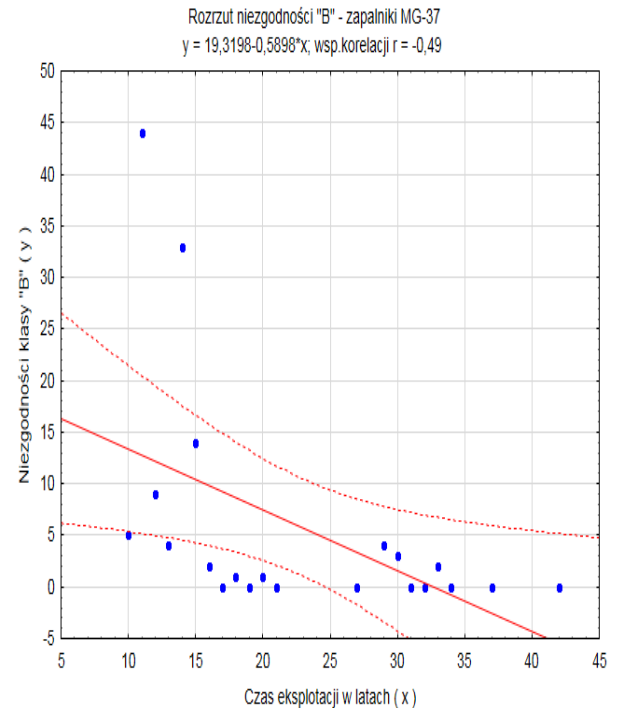

Rys. 23 Niezgodności klasy B po badaniach strzelaniem $w$ zależności od czasu eksploatacji oraz linia regresji opisujaca ta zależność dla zapalników MG-37

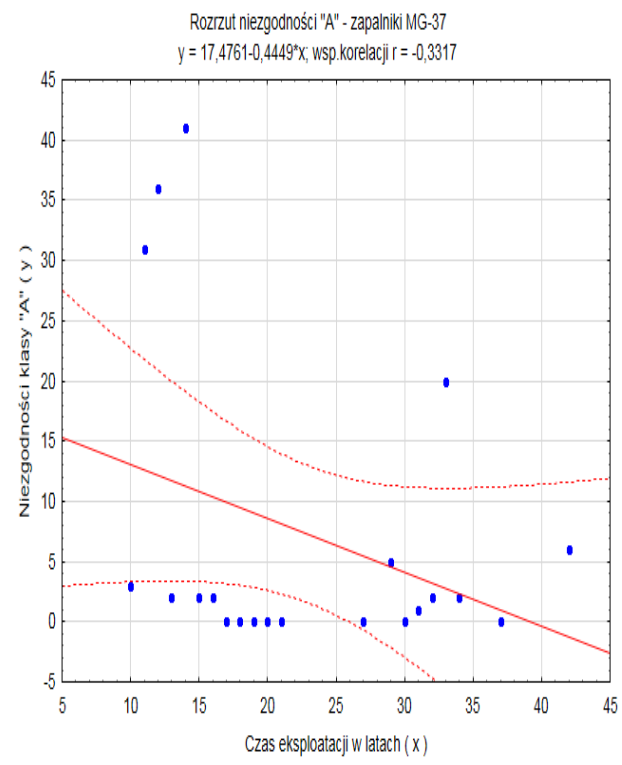

Rys. 22 Niezgodności klasy A po badaniach strzelaniem $w$ zależności od czasu eksploatacji oraz linia regresji opisująca ta zależność dla zapalników $M G-37$

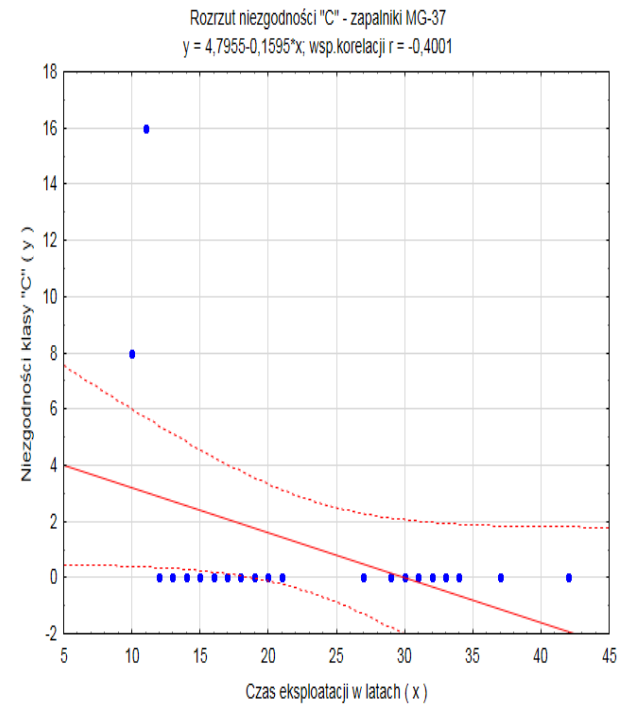

Rys. 24 Niezgodności klasy C po badaniach strzelaniem $w$ zależności od czasu eksploatacji oraz linia regresji opisujaca ta zależność dla zapalników MG-37 


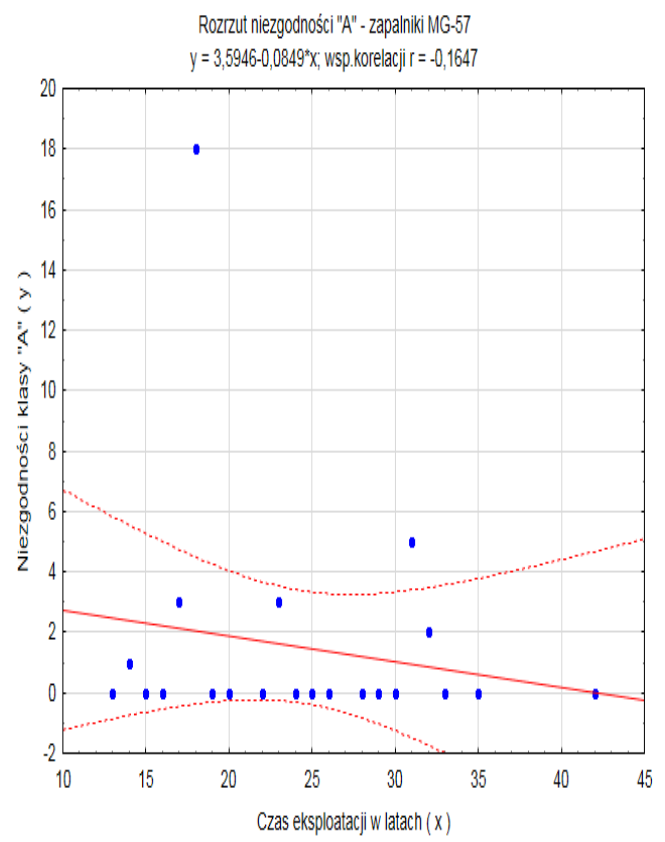

Rys. 25 Niezgodności klasy A po badaniach strzelaniem $w$ zależności od czasu eksploatacji oraz linia regresji opisujaca ta zależność dla zapalników $M G-57$

W przypadku zapalników typu MG-57 analizowano tylko niezgodności klasy A (rys. 25). Mają one również tendencję malejącą czyli w miarę upływu czasu eksploatacji ich ilość spada. Wartość współczynnika korelacji liniowej wynosi $\mathrm{r}=-0,1647$.

\section{Podsumowanie}

W artykule, przedstawiono szczegółową analizę statystyczną zapalników artyleryjskich typu M-5, MD-8, MG-37, MG-57 i T-5. Celem tego artykułu było pokazanie tendencji zmian starzeniowych zachodzących $\mathrm{w}$ analizowanych zapalnikach na podstawie wyników badań uzyskanych $\mathrm{w}$ badaniach laboratoryjnych i w badaniach dynamicznych strzelaniem. Wyznacznikiem tych zmian były uzyskane decyzje podiagnostyczne oraz ilości niezgodności stwierdzone podczas tych badań diagnostycznych. Dodatkowym celem artykułu była również weryfikacja podjętych decyzji diagnostycznych badać strzelaniem pod kątem możliwości modyfikacji modułu ocenowego funkcjonującego w metodyce badawczej zapalników artyleryjskich.

Analiza zależności frakcji decyzji strzelaniem w relacji do czasu eksploatacji wykazała, że frakcja ta ma różny charakter zmian w zależności od rozpatrywanego typu zapalnika. Widać różne tendencje zmian, w przypadku analizowanych zapalników M-5, MD-8 i T-5 jest to tendencja wzrastająca, natomiast w przypadku zapalników typu MG-37 i MG-57 następuje spadek frakcji decyzji strzelaniem wraz z upływem czasu eksploatacji. 
Verification postdiagnostic decisions tested of artillery fuses

Weryfikacja decyzji podiagnostycznych badanych zapalników artyleryjskich

W przypadku analizy rozrzutu niezgodności różnych klas w zależności od czasu eksploatacji, jakie zostały wykryte po badaniach laboratoryjnych, widzimy także różny charakter tych zmian.

Zapalniki typu M-5 wykazują tendencję spadkową dla niezgodności klasy A i B, natomiast niezgodności klasy $\mathrm{C}$ nie były rozpatrywane. Zapalniki typu MD-8 wykazują także tendencję spadkową w przypadku niezgodności A i C, natomiast w przypadku niezgodności klasy B utrzymują się praktycznie na stałym poziomie ich występowania. W przypadku zapalników typu MG-37 i MG-57 analizowano tylko niezgodności klasy $\mathrm{C}$, które mają spadkowy charakter zmian. Pozostałe klasy niezgodności nie wystąpiły w ilości wskazanej do przeprowadzenia analizy statystycznej. Zapalniki typu T-5 były rozpatrywane $\mathrm{w}$ trzech klasach niezgodności. W przypadku niezgodności klasy A i B mamy do czynienia ze spadkiem ilości niezgodności $\mathrm{w}$ miarę upływu czasu eksploatacji, natomiast niezgodności klasy $\mathrm{C}$ wykazały lekki wzrost ich ilości.

Analiza zależności frakcji podjętych decyzji dodatnich po przeprowadzonych badaniach strzelaniem w relacji od czasu eksploatacji, nie była rozpatrywana dla zapalników typu T-5, ze względu na przeprowadzone tylko trzy strzelania tego typu zapalników. Natomiast w przypadku zapalników typu M-5, MD-8 i MG-57 widać tendencję spadkową frakcji decyzji dodatnich, tylko zapalniki typu MG-37 wykazały się tendencją wzrostową.

W przypadku analizy rozrzutu niezgodności w poszczególnych klasach po przeprowadzonych badaniach dynamicznych strzelaniem w zależności od czasu eksploatacji, rozpatrywane były tylko niektóre klasy niezgodności ze względu na zbyt małą ilość ich występowania. Dla zapalników typu M-5 analizowano tylko niezgodności klasy $\mathrm{B}$, które mają wyraźny rosnący charakter zmian. Dla zapalników typu MD-8 rozpatrywano także tylko jedną klasę niezgodności, a mianowicie niezgodności klasy A, które także mają rosnący charakter zmian. Kolejnym zapalnikiem $\mathrm{z}$ analizowaną tylko jedną klasą niezgodności były zapalniki MG-57, w których niezgodności klasy A mają tendencję spadkową. Tylko zapalniki typu MG-37 były rozpatrywane we wszystkich klasach niezgodności. We wszystkich klasach niezgodności A, B i C widzimy wyraźną spadkową tendencję w miarę upływu czasu eksploatacji.

Reasumując można stwierdzić, że przeprowadzone badania diagnostyczne analizowanych w tym artykule wybranych typów zapalników artyleryjskich, spowodowały podjęcie zgodnie $\mathrm{z}$ obowiązującą metodyką badawczą, decyzji o badaniu dynamicznym strzelaniem tych partii zapalników. Jednakże, w wyniku przeprowadzonej tej dokładnej analizy statystycznej, nasuwać się mogą wnioski, które mogą sugerować, że badania strzelaniem można by pominąć $\mathrm{w}$ procedurze ocenowej badań laboratoryjnych. 
Podjęte decyzje diagnostyczne po przeprowadzonych badaniach strzelaniem, potwierdzają przypuszczenie, że badane partie zapalników, były w dobrym stanie technicznym. Świadczą o tym fakcie podjęte dodatnie decyzje diagnostyczne po badaniach dynamicznych czyli decyzje $\mathrm{Z}$ - zużyć w pierwszej kolejności.

$\mathrm{Na}$ podstawie tej analizy, należało by się zastanowić nad zmianą modułu ocenowego po przeprowadzonych badaniach laboratoryjnych. Autor tego artykułu wysuwa taką możliwość, mając wiedzę badawczą z zakresu szeregu analiz przeprowadzonych także na innych typach zapalników artyleryjskich oraz innych elementach amunicji. Bardzo ważnym argumentem ku temu jest fakt, iż badania dynamiczne strzelaniem są badaniami drogimi w ich wykonaniu, przekraczającymi kosztowo znacznie badania laboratoryjne. Modyfikacja systemu ocenowego nie wpłynie negatywnie na jakość prowadzonych badań diagnostycznych, ani też nie wpłynie negatywnie na prawidłową ocenę procesu predykcji badanych elementów środków bojowych jakimi są zapalniki artyleryjskie. Wskazana jest zatem, zdaniem autora ze względów kosztowych, zmiana tego modułu ocenowego i uwzględnienie tych zmian w nowej metodyce badawczej.

Dobrym rozwiązaniem w ocenie autora artykułu, byłoby zastąpienie decyzji BS badać strzelaniem w module ocenowym podczas badań laboratoryjnych, decyzją PS - badać według programu specjalnego. Modyfikacja taka nie wpłynie na obniżenie określania prawidłowości predykcji bezpiecznych okresów eksploatacyjnych dla badanych zapalników artyleryjskich. Nie wpłynie ona także na zmniejszenie niezawodności działania tych zapalników. Spowoduje natomiast możliwość dalszej bezpiecznej eksploatacji partii zapalników składowanych w zasobach Wojska Polskiego. Do momentu braku zakończenia cyklu badawczego, każda badana partia zapalników jest w tzw. zawieszeniu i nie można nic z taką partią zrobić. Z informacji własnej autora artykułu wynika, że na badania strzelaniem oczekuje ponad 100 partii spośród typów zapalników analizowanych w tym artykule. Nawet podjęcie decyzji o utylizacji danej partii, przed zakończeniem cyklu badawczego, może powodować pewne sugestie dla organów kontrolnych o dokonanej szkodzie $\mathrm{w}$ mieniu wojskowym. Z związku z powyższym, aby zmniejszyć ilość partii zapalników zawieszonych w eksploatacji, wskazana jest modyfikacja tego modułu ocenowego według propozycji autora przedstawionej w tym artykule.

\section{Literatura}

[1] Praca zbiorowa - Metodyka badań diagnostycznych amunicji - Indeks N5001b - 1985r. Archiwum WITU;

[2] Podręcznik - Amunicja wojsk ladowych - Ministerstwo Obrony Narodowej Szefostwo Służby Uzbrojenia i Elektroniki 1985 r.;

[3] Statystyka 10 - Statsoft Polska 2010 r. - oprogramowanie komputerowe. 
Verification postdiagnostic decisions tested of artillery fuses Weryfikacja decyzji podiagnostycznych badanych zapalników artyleryjskich

[4] Sprawozdania z badań środków bojowych - Archiwum WITU.

[5] Karty badań laboratoryjnych zapalników - Archiwum WITU.

[6] Karty badań strzelaniem zapalników - Archiwum WITU.

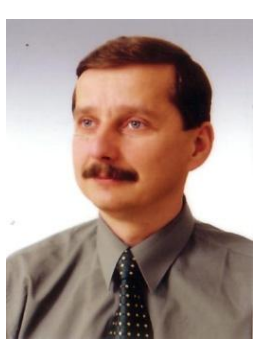

Dr inz. Dariusz Ampula, absolwent Wojskowej Akademii Technicznej w zakresie Systemów Uzbrojenia Naziemnego. Po odbyciu rocznej praktyki zawodowej zostat pracownikiem naukowo-badawczym $w$ Wojskowym Instytucie Technicznym Uzbrojenia w Zielonce. Stopień naukowy doktora uzyskat w 2006 roku $w$ Instytucie Technicznym Wojsk Lotniczych. Autor $i$ wspótautor prac z zakresu diagnostyki technicznej oraz niezawodności działania ladowych środków bojowych. W swoich analizach badawczych skupia się na problemach procesu predykcji badanych elementów amunicji ladowej. 